\title{
IS THERE A TRADEOFF \\ BETWEEN UNEMPLOYMENT AND \\ PRODUCTIVITY GROWTH?
}

Robert J. Gordon

Working Paper No. 5081

\author{
NATIONAL BUREAU OF ECONOMIC RESEARCH \\ 1050 Massachusetts Avenue \\ Cambridge, MA 02138 \\ April 1995
}

This research was supported by the National Science Foundation. David Rose and Gareth Siegel provided outstanding help with the data and tables. Bart van Ark, Eric J. Bartelsman, and Charles Bean provided essential data on hours per employee. Charles Bean and Dennis Snower provided important comments on an earlier draft. Because of the paper's length, it is not possible to include here either appendix tables nor the explanation of data sources. These are readily available from the author. This paper is part of NBER's research programs in Economic Fluctuations, International Finance and Macroeconomics, Labor Studies and Productivity. Any opinions expressed are those of the author and not those of the National Bureau of Economic Research.

(C) 1995 by Robert J. Gordon. All rights reserved. Short sections of text, not to exceed two paragraphs, may be quoted without explicit permission provided that full credit, including (C) notice, is given to the source. 
IS THERE A TRADEOFF

April 1995

\title{
BETWEEN UNEMPLOYMENT AND \\ PRODUCTIVITY GROWTH?
}

\begin{abstract}
This paper shows how misleading is the facile contrast of Europe following a path of high productivity growth, high unemployment, and relatively greater income equality, in contrast to the opposite path being pursued by the United States. While structural shocks may initially create a positive tradeoff between productivity and unemployment, they set in motion a dynamic path of adjustment involving capital accumulation or decumulation that in principle can eliminate the tradeoff.

The main theoretical contributions of this paper are to show how a productivityunemployment tradeoff might emerge and how it might subsequently disappear as this dynamic adjustment path is set in motion. Its empirical work develops a new data base for levels and growth rates of output per hour, capital per hour, and multifactor productivity in the G-7 nations both for the aggregate economy and for nine sub-sectors. It provides regression estimates that decompose observed differences in productivity growth across sectors. It finds that much of the productivity growth advantage of the four large European countries over the United States is explained by convergence and by more rapid capital accumulation, and that the only significant effect of higher unemployment is to cause capital accumulation to decelerate, thus reducing the growth rate of output per hour relative to multi-factor productivity.
\end{abstract}

Robert J. Gordon

Department of Economics

Northwestern University

Evanston, IL 60208-2600

and NBER 


\section{INTRODUCTION}

Over the past decade there has been a steady divergence in the interests of European and American macro and labour economists. Persistently high unemployment in Europe has held center stage in the concerns of Europeans, and little consensus has emerged regarding the share of blame to be attributed to cyclical or structural factors, nor on the particular mix of structural factors to be held responsible. In the United States, by contrast, there is near total agreement that fluctuations in unemployment have been cyclical in nature, and that the underlying "Non-Accelerating Inflation Rate of Unemployment" (NAIRU) has changed little over the past two decades. Since there are few puzzles in the behavior of unemployment, American economists have increasingly shifted their emphasis toward the view that the central problems of the U. S. economy are (1) slow growth in productivity and in real wages, and (2) an increasing dispersion of the income distribution that has resulted in an absolute decline in real wages for workers below the 20 th or even 50th percentile (depending on the exact measure used).

This paper explores the hypothesis that the divergence of emphasis across the Atlantic is misplaced, and that the apparently separate problems of high unemployment in Europe and low productivity growth in America may be interrelated. Is there a tradeoff between low unemployment and high productivity growth? If so, what factors have caused Europe and America to move to different positions on the unemployment-productivity tradeoff schedule? What events and policies can cause this schedule to shift in a favorable or unfavorable direction? Are there policies that Europe could adopt that would reduce structural unemployment without eroding its advantage over the United States of faster productivity growth? In parallel, could the United States adopt policies that would boost 


\section{The Unemployment - Productivity Tradeoff, Page 2}

productivity growth without creating extra structural unemployment?

The connection between unemployment and productivity is implicit in virtually everything written on European unemployment in the past decade. Any autonomous event that boosts the real wage (e.g., an increase in the minimum wage or in trade union bargaining power) will shift the economy northwest along a labour demand curve, simultaneously raising unemployment and labour's marginal (and average) product. Obviously this mechanism could work in reverse if policies are adopted that reduce labour cost and shift the economy southeast along a labour demand curve, simultaneously reducing unemployment and labour's marginal (and average) product. Yet it is remarkable that virtually no attention has been paid in Europe to the possibility that there could be a productivity sacrifice as a cost of particular labour market reforms. In fact, most European discussions of the interplay between productivity and unemployment take productivity growth to be exogenous and ask whether the post-1973 productivity growth slowdown could have caused high European unemployment if real wage growth "aspirations" failed to slow down in tandem with the productivity available to finance those aspirations. ${ }^{1}$

Similarly, the U. S. literature on slow real wage growth almost always adopts the convention of assuming that productivity growth and its post-1973 slowdown are exogenous, and that the fundamental cause of slow real wage growth is the poorly understood and independent behavior of productivity. In the many analyses of the productivity growth slowdown, the long "laundry list" of possible causes rarely if ever includes slow real wage growth, i.e., reverse causation. ${ }^{2}$ The standard European version of 
the labour demand-supply diagram, often used to illustrate how a wage bargaining shock can raise unemployment and (implicitly) productivity, has not been used in reverse to explain how low American productivity growth might be the result of some event that slides the economy southeast down its labour demand curve.

Not only is there a transatlantic divide in the interests of European and American economists, but there is also an asymmetry in the degree to which they look to the other side of the Atlantic for solutions. While American economists have devoted little attention to European practices and institutions as providing lessons for the United States, in contrast many Europeans have pointed to the "flexibility" of the U. S. labour market as a likely source of the lower unemployment rate in the United States than in Europe and as providing a desirable model for European reforms. However, the fact that buoyant U. S. employment growth has been accompanied by growing income inequality has more recently caused European economists to draw back from unqualified admiration of U. S. labour market institutions. ${ }^{3}$ In Europe at present there is an active search for policies that might reduce unemployment without having adverse side effects on productivity or the income distribution - these are policies that we shall describe as shifting the unemploymentproductivity tradeoff schedule in a favorable direction.

\section{Contribution of This Paper}

This paper provides a new perspective on alternative policies designed to reduce European unemployment. It introduces the idea of the unemployment-productivity tradeoff schedule and distinguishes between policies that move a country along a given schedule and 
those that shift the schedule. The productivity impact of alternative anti-unemployment policies therefore becomes a criterion, little discussed previously, for choosing among these policies. However, the paper shows how misleading is the facile contrast of Europe following a path of high productivity growth, high unemployment, and relatively greater income equality, in contrast to the opposite path being pursued by the United States. Many structural shocks that initially create a positive tradeoff between productivity and unemployment set in motion a dynamic path of adjustment involving capital accumulation or decumulation that in principle can eliminate the tradeoff.

The main theoretical contributions of this paper are to show how a productivityunemployment tradeoff might emerge and how it might subsequently disappear as this dynamic adjustment path is set in motion. Its empirical work develops a new data base for levels and growth rates of output per hour, capital per hour, and multifactor productivity in the G-7 nations both for the aggregate economy and for nine sub-sectors. It provides regression estimates that decompose observed differences in productivity growth among convergence, capital accumulation, sector-specific, and time-trend effects, and asks whether there is any persistent tradeoff between productivity and unemployment.

\section{FACTS ABOUT UNEMPLOYMENT AND PRODUCTIVITY}

We look first at some basic facts about unemployment and productivity. Those about unemployment are extremely familiar, those about productivity somewhat less so. 
The Unemployment - Productivity Tradeoff, Page 5

\section{Unemployment and EmploymentPopulation Ratios}

The evolution of the standardized unemployment rate is shown in Figure 1. The contrast between the experience of the U. S. and the EC is familiar. The U. S. has exhibited large fluctuations in its unemployment rate but the series is basically stationary, with no change between 1972 and 1989, a temporary cyclical increase between 1989 and 1992, and a cyclical decline between 1992 and 1994. The EC unemployment series displays an inexorable rise from the early 1970 s to 1985 , a cycical recovery through 1990 , and a cyclical rise back into double digits in 1991-94. As always, Japan is an outlier, with an extremely low mean unemployment rate and low volatility as well. Because of the peculiar nature of the Japanese labour market, in which cyclical fluctuations in output are absorbed much less than in other countries by changes in unemployment - and much more by changes in hours, participation, and productivity - this paper will largely ignore the Japanese experience and will concentrate on differences between Europe and the United States.

The contrast in Figure 1 between a 1994 EC unemployment rate of 11.8 percent and a U. S. rate of 6.1 percent greatly understates the contrast between labour-market performance. Figure 2 displays employment-population (E/P) ratios, with and without an adjustment for changes in hours of work, for OECD Europe and the U.S. Here the raw E/P ratios differ in 1990 by 11 percent, and the gap grows to 14 percent if the differing evolution of hours per employee is taken into account. While some fraction of the relative drop in European working hours is surely voluntary, taken in the form of longer vacations, 
nevertheless another fraction results from the pressure for shorter hours (especially in Germany) to spread the burden of high unemployment.

The best-known contrast between the EC and the rest of the OECD is in the percentage of unemployment taking the form of long-term unemployment (defined as unemployed for longer than one year). Figure 3 shows that, while in 1992 this percentage clustered in the range 12-16 percent for North America, EFTA, and Japan, it was 42 percent in the EC, down from a peak of 55 percent during 1985-89. As is well-known, for any given aggregate unemployment rate, the EC has a much higher share in the form of long-

term unemployment. For instance, the aggregate unemployment rate in the U. S. in 1982-83 was higher than in the EC in 1989-91, but the long-term percentage was only 10 percent as contrasted with 50 percent.

\section{Productivity Growth, Wage Shares, and Wage Dispersion}

Is there a tradeoff between low unemployment and fast productivity growth? The unemployment data for three regions in Figure 1 can be contrasted with the essential facts about productivity provided in Figure 4. Here we focus on multi-factor productivity (MFP), which subtracts from output growth a weighted average of growth in two inputs, hours and capital.

Figure 4 displays several well-known facts about international productivity growth differentials, and several others that are less well-known. First, all three regions experienced a marked slowdown of MFP growth after 1973. Second, U. S. MFP growth was slower than in the other regions in all three periods. Less well-known are, third, that the extent of the 
slowdown between the first and last period (1960-73 to 1979-93) was greatest in Japan (3.9 points), next in Europe (2.2 points), and smallest in the U. S. (1.2 points). Fourth, MFP in Europe actually grew at the same rate as in Japan during 1973-79 and only moderately slower during 1979-93. The average growth rates for the full 1973-93 period were 0.16 percent for the U. S., 1.16 for Europe, and 1.51 for Japan.

Not shown separately are growth rates of productivity defined as output per employee. Of the four facts listed above, only the last is slightly changed, according to this alternative measure. Output per employee grew faster in Japan than in Europe in all three periods, but not by a large margin. The average growth rates for the full 1973-93 period were 0.56 percent for the U. S., 2.11 for Europe, and 2.76 percent for Japan.

On the face of it, there is not much support in these numbers for an unemploymentproductivity tradeoff. Japan had lower unemployment and faster productivity growth than the other regions. However, in order to give the hypothesis a chance, we can rule out Japan as a "special case" with unusually dynamic rates of technological advance and an unusually flexible labour market. Perhaps more troubling is the fact that European productivity growth was faster than in the U. S. throughout the postwar period, yet unemployment (for the EC) was higher only after 1982. In fact, the productivity growth differential between OECD Europe and the U. S. was narrower after 1979 than before. However, this does not rule out the possibility that at the margin some aspects of labour market structure and policy may boost both unemployment and productivity growth in Europe, while the same or other aspects may reduce unemployment and productivity growth in the U.S. In this view, the 
The Unemployment - Productivity Tradeoff, Page 8

uniform superiority of European productivity growth in all three time periods could be attributed to some basic factor not related to labour market structure and policy, particularly technological convergence. ${ }^{s}$

The most recent facts on convergence are assembled in Table 1, using 1990 OECD measures of purchasing-power-parity. Measured by GDP per capita relative to the U. S., other members of the G-7 have reached from 74 to 89 percent of the U. S. level. A more relevant metric for discussions of technological convergence is output per hour, and Table 1 reports the surprising fact that France and Germany have already overtaken the U. S., while Japan lags far behind.

Empirical work on convergence has been the main focus in recent years of economists interested in economic growth. Unfortunately, results are quite sensitive to data sources and methodology. In contrast to sterling performance of Germany in Table 1, a recent study that makes a basic reevaluation of the data and methodology concludes that (as of 1987) no country in OECD Europe had come within 18 percent of the level of U. S. total factor productivity. ${ }^{6}$

Has the growth of real wages duplicated the growth of productivity? By definition, Labour's income share $(S)$ is equal to the real wage $(W / P)$ divided by output per hour $(Q / H)$. Using lower-case letters for logs, this definition implies that the growth rate of the real wage is equal to the growth rate of productivity plus the growth rate of labour's share:

$$
(\Delta w-\Delta p)=(\Delta q-\Delta h)+\Delta s
$$


The Unemployment - Productivity Tradeoff, Page 9

There has been much discussion in the U. S. literature about the failure of real wages to grow over the past two decades, despite a positive (albeit small) growth rate of output per hour. In the American view, structural features of U. S. labour markets account for the failure of real wages to keep pace with productivity, in contrast with Europe where faster productivity growth has been accompanied by growth in real wages at approximately the same rate. According to equation (1), this common perception implies that the U. S. wage share must have declined substantially. For zero real wage growth to be consistent with a 1.0 percent annual rate of productivity growth, labour's share would have to decline at 1.0 percent per year, for instance from 70 percent in 1973 to 53 percent in 1993.

This common U.S. perception appears to be the reverse of the truth, as shown by the display of wage shares in Figure 5. These wage share series, constructed by the OECD, include in wage income an imputation for the labour income earned by the self-employed. Far from declining rapidly, the wage share series for the U.S. has remained roughly constant, falling only from 68 percent in 1973 to 66.5 percent in 1993 . The wage share series for the EC has declined much more, from peaks of 70 percent in 1975 and 69 percent in 1981 to 64 percent in 1993.

What explains the contradiction between the actual behavior of the wage share and the widespread U. S. perception that wage growth has stagnated while productivity growth has remained positive? Recently this question was exhaustively reviewed by Bosworth and 
Perry (1994), not just for the U. S. but for the G-7. Bosworth-Perry consider a number of reasons why the standard real average hourly earnings series published monthly for the U. S. understates the growth in true real compensation, including sources of upward bias in the consumer price index (CPI) and downward bias in the index of average hourly earnings (which excludes non-wage compensation, excludes fringe benefits, and ignores the bias introduced as job growth occurs more rapidly in areas - e.g., the southern states - with a lower true cost-of-living index).

Perhaps the greatest contrast between the U. S. and Europe concerns the growth of real wages for those in the bottom decile of the wage distribution. Figure 6 displays the growth of real earnings of males at the 10th percentile of the wage distribution. The unhappy results for the U. S. are slightly biased downward by use of the CPI as a deflator, but there is no doubt that the combination of (1) slow overall U. S. productivity growth and, (2) a significant increase in the dispersion of incomes, has placed the rate of income growth of poor Americans at the bottom of the G-7 league table.

\section{Implications}

This review of international data is merely suggestive. Japan must be ruled out of any investigation of a tradeoff between low unemployment and rapid productivity growth, since it has enjoyed both and seems to lie well outside of any frontier that could define such a tradeoff for the major economies of Europe and North America. The primary facts that suggest that such a tradeoff might exist are the combination of relatively high unemployment rates in the EC nations together with a rate of productivity growth that considerably exceeds 
that in the U.S. From the perspective of the U.S., the ongoing dilemma of slow real income growth, particularly at the bottom of the income distribution, opens up the possibility that some aspects of flexible U. S. labour market institutions may have contributed to slow productivity growth.

\section{BASIC ANALYTICS}

Our theoretical discussion begins by setting out the unemployment-productivity tradeoff (UPT) schedule. We then provide an interpretation of this schedule in terms of the standard labour market model so often used to analyze the persistence of European unemployment. That model helps then helps us to distinguish between factors that cause movements along the UPT schedule and those factors that cause the UPT schedule to shift its position.

\section{The Unemployment-Productivity Tradeoff (UPT) Schedule}

The UPT schedule can be drawn in terms of levels or changes. Figure 7 illustrates the version expressed in terms of changes, plotting the change in output per hour on the vertical axis against the change in the unemployment rate on the horizontal axis. The "change" version of the UPT schedule is intended to focus on developments over the length of one business cycle or longer, e.g., causes of changes in the unemployment rate over the 15 -year period between 1979 and 1994 . The point labelled "U. S." is plotted at zero on the horizontal axis, reflecting the fact that the U. S. had no change in its unemployment rate between 1979 and 1994, while the point labelled "Europe" is plotted further to the right, 
reflecting the fact that the unemployment rate for the EC more than doubled, from 5.7 percent in 1979 to 11.8 percent in 1994 . In the vertical direction the change in productivity for Europe is greater than for the U. S., reflecting the contrast that we previously discussed in connection with Figure 4.

Why do we focus on the change version of the UPT schedule rather than the level? By most measures the level of labour productivity is still higher in the U. S. than in Europe, and so a plot of the level of productivity vs. the level of unemployment for the U. S. and Europe would have a negative slope. The high level of productivity is the U. S. is assumed to reflect historical factors dating back before 1960 , whereas we want to examine the consequences of more recent changes in structure and in policies on the evolution of productivity and the unemployment rate. The change version of the UPT schedule allows us to "factor out" contributions to the high level of U. S. productivity the predate the period of interest.

It is important to note that the vertical axis of the UPT diagram refers to the change in output per hour, not the change in MFP. Using the same notation as in equation (1) above, and designating the change (or growth rate) of MFP as $\Delta a$, the growth rate of capital as $\Delta k$, and the elasticity of output to a change in capital as $(1-\alpha)$, the change in output per hour is:

$$
\Delta q-\Delta h=\Delta a+(1-\alpha)(\Delta k-\Delta h) .
$$

Equation (2) neatly separates factors that account for the positive slope of the UPT schedule 
from those that account for shifts in that schedule. Any positive change in $\Delta a$ shifts the schedule up and a negative change shifts the schedule down. In contrast, any event (labelled below as a "wage setting shock") that causes an increase in $\Delta k-\Delta h$ by simultaneously raising unemployment while reducing employment (and hours), for a given growth rate of capital, causes the economy to move northeast along the UPT schedule from a point like that marked "U. S." to a point like that marked "Europe." Finally, for any given change in unemployment and employment, a downward shift in the growth rate of capital shifts the UPT schedule downward, just as does a reduction in $\Delta a$.

The initial focus in our analysis is on factors that cause movements along the UPT schedule, while subsequently we examine factors that cause adverse or favorable shifts in the schedule. The ultimate goal is to distinguish unemployment-reducing policies for Europe that tend to have an adverse impact on productivity (moving Europe southwest from its position in Figure 7) from those that do not.

\section{The Standard Labour-Market Model}

The relationship between unemployment and productivity is implicit in the standard labour market model so often used to discuss the persistence of European unemployment. Figure 8 incorporates three relationships. First, the kinked line $N^{s}$ is a labour supply curve, relating the total labour force plotted horizontally to the level of the real wage plotted vertically. At the level of unemployment benefits $(W / P)_{B}$ the schedule is horizontal while at higher levels of the real wage the schedule is vertical, following the weight of evidence suggesting that this relationship is highly inelastic. 
Second, the downward-sloping $N^{D}$ curves represent the negative relationship between the level of employment and the real wage. In elementary textbooks, this relationship is interpreted as reflecting the price-taking, profit-maximizing behavior of firms operating in competitive labour markets. For such firms, employment is determined by setting the real wage equal to the marginal product of labour, which is assumed to be subject to diminishing returns with increased employment. Thus, for this analysis to be consistent with a production function exhibiting constant returns to scale, the quantity of other factors of production (especially capital, energy, and materials) is held constant along any particular $N^{D}$ curve. However, in much of the recent literature this graphical analysis has been shown to be consistent with imperfectly competitive product markets in which prices are set as a mark-up on marginal labour cost. In this case, any tendency for the markup to increase with the level of employment would increase the negative slope of the schedule. In the imperfectly competitive case these downward sloping schedules reflect the joint outcome of pricing and employment decisions by firms and are sometimes called "price setting" schedules.

In contrast to the traditional textbook diagram, in which the upward sloping lines are called labour supply schedules, in the recent literature these are called wage-setting schedules $\left(W^{5}\right)$. Higher employment is postulated to elicit higher real wages as the outcome of bargaining between unions and employer associations and is also consistent with the efficiency wage model. As employment increases, the bargaining power of workers is postulated to increase. 
In Figure 8 , the economy is initially in equilibrium at point $A$ along curves $N_{0}^{D}$ and $W^{s}$, equilibrium employment is represented by $E_{0}$ and equilibrium unemployment $\left(U_{0}\right)$ by $N_{0}-E_{0}$. In the competitive interpretation of the labour demand curve, the marginal product of labour is $(W / P)_{0}$, and in the special Cobb-Douglas case, the average product of labour is $(W / P)_{0} / s$, where $s$ is labour's income share.

\section{Wage Setting Shocks}

Now, let us examine two types of shocks and inquire into the circumstances in which an increase in unemployment could coincide with an increase in the level of productivity (which in our discussion of the labour-market diagram refers to output per employee, since hours per employee are assumed fixed, as is MFP). First, consider a wage-setting shock that shifts the $W^{s}{ }_{0}$ curve upwards to the position $W^{s}$. Such a shock might be caused by an autonomous increase in the bargaining power of trade unions, or in any event (like the French general strike of spring 1968) in which a given group of workers bands together and autonomously raises the wages that it requires to supply a particular amount of employment. The result of such a wage-setting shock is to move the economy from point $A$ to point $B$, where the original labour demand curve $N^{D}{ }_{0}$ intersects the new higher $W^{s}{ }_{1}$ curve.

Such a wage-setting shock establishes a tradeoff between higher unemployment and higher output per employee. At point $B$ unemployment has risen from $U_{0}$ to $U_{1}$, while the marginal product of labour has risen from $(W / P)_{0}$ to $(W / P)_{1}$. In the Cobb-Douglas case, the average product of labour increases in proportion to the marginal product.

The economy, however, is unlikely to settle at point $B$ for long. Compared to point 
$A$, at point $B$ output and employment are lower, and the marginal product of capital has fallen because the fixed stock of capital is being combined with less labour input. The demand for capital will fall, and a period of disinvestment will occur that shifts the labour demand curve down and to the left to a position like $N^{D}{ }_{1}$. If the higher wage setting schedule remains in effect, then on standard assumptions about the structure of the model, the labour demand curve must shift downwards to the point at which the new wage-setting schedule intersects the original real wage $(W / P)_{0}$, as shown at point $C$ in Figure $8 .^{8}$

Once the process of adjustment in capital input is completed, unemployment has grown from the initial level $U_{0}$ to the intermediate level $U_{1}$ to the final level $U_{2}$. However, at point $C$ we do not observe a tradeoff between unemployment and output per hour, since the marginal and average products of labour have returned to their initial values (the same at point $C$ as at point $A$ ), while unemployment has increased greatly. However, this model does help : .pture a key feature of the European unemployment puzzle of the 1980s and 1990 s - at point $C$ there has been a substantial increase in the unemployment rate without any decline in the rate of capacity utilization, which is assumed to be constant in the model. At point $C$ Europe has "disinvested" and substantially reduced the ratio of capital to the labour force, without reducing at all the ratio of capital input to labour input. Unemployment has occurred in an environment of disinvestment in which there is now insufficient capital fully to employ the labour force $\left(N_{0}\right)$.

Indeed, a notable feature of the permanent rise in European unemployment in the 1980 s is that this rise was not accompanied by a permanent drop in capacity utilization. For 
instance, German unemployment was higher in 1990 than in 1979 but so was the rate of capacity utilization. As shown by Franz-Gordon (1993), the mean-utilization unemployment rate ("MURU") for Germany has increased almost as much as the actual unemployment rate, implying that there no longer exists sufficient productive capacity to provide jobs for enough people to attain the unemployment rates of the 1970s, much less the 1960s. Bean (1994, p. 613) shows that the same phenomenon has occurred for the European Community as a whole.

\section{Energy Price Shocks}

Most European discussions of the productivity-unemployment connection have in mind not wage-setting shocks but rather the effects of the oil shocks, and these can be illustrated in Figure 9. An increase in the real price of oil shifts down the labour demand curve to schedule $N^{D}{ }_{1}$, by reducing the quantity of energy and hence the marginal product of labour. ${ }^{9}$ Starting from point $A$, the economy's equilibrium position shifts southwest to point $D$. As before, unemployment has increased and the marginal product of labour has fallen from $(W / P)_{0}$ to $(W / P)_{2}$ and (in the Cobb-Douglas case) the average product of labour falls in proportion.

Thus far we have learned that a shock that increases unemployment may either raise or lower productivity. An adverse productivity shock can create a negative correlation between the level of unemployment and the level of productivity, while a wage-setting shock can create a positive correlation between the level of unemployment and the level of productivity, at least over the period of time prior to the downward adjustment of the 
capital stock to the wage-setting shock.

How does the cconomy adjust to an energy price shock? Several possibilities are illustrated in Figure 9, where points $A$ and $C$ represent the same situation as in Figure 8. During the early 1980s the seminal work of Branson-Rotemberg (1980), Sachs (1979), and Bruno-Sachs (1985), emphasized the contrast between real wage rigidity in Europe and real wage flexibility in the U.S. Taken literally, this dichotomy would imply that a given adverse energy price shock would shift Europe from point $A$ to point $C$, as the result of a horizontal wage setting curve. In contrast, the same shock would shift the U. S. from point $A$ to point $H$, as the result of flexible wage-setting institutions that cause the wage-setring curve to shift down until it intersects the lower labour demand curve at the original level of employment.

Other possibilities are suggested by Elmeskov and MacFarlan (1993), who use the same diagram to interpret the concept of hysteresis. With full hysteresis, the equilibrium unemployment rate depends on the current unemployment rate. Following an energy price shock (or an adverse aggregate demand shock) that shifts the labour demand curve in Figure 9 from $N_{0}^{D}$ to $N^{D}{ }_{1}$ the economy moves from $A$ to $D$, as before. But under full hysteresis there is a vertical long-run wage-setting schedule $W^{s^{\prime}}$ which moves to the current level of employment. Under partial hysteresis or "slow adjustment," the wage setting schedule does not shift down all the way to point $H$ but comes to rest at a schedule like $W^{s}{ }_{2}$, and employment is prevented from rising above $E_{3}$. In short, points $C, D, G$, and $H$ (all of which lie along the lower labour demand curve $N^{D}{ }_{1}$ ) represent alternative responses to an adverse productivity shock under the extremes of real wage rigidity and full flexibility, and 
the intermediate cases of full and partial hysteresis.

We note that, while the event of an adverse energy price shock can create a negative correlation between unemployment and productivity, any adjustment following the shock along the labour demand curve (e.g., between points $C$ and $H$ ) can create a positive correlation. In this sense any slow or gradual adjustment of wage setting following a shock creates the same positive correlation between unemployment and productivity as occurs in Figure 8 following a wage-setting shock.

Much of the literature in the early 1980s, e.g., Bruno-Sachs (1985), emphasized that labour's share of national income had risen in Europe at the time of the first energy price shock, and took this as prima facie evidence that European unemployment was structural, caused by excessive real wage rigidity. As pointed out by Krugman (1987, pp. 60-65), Bean (1994, p. 577), and others, there is no such necessary link between real wage rigidity and labour's share. If the labour demand curve $N_{1}^{D}$ is derived from a Cobb-Douglas production function, then labour's share cannot change at all under the assumptions of perfect competition and constant returns. Any observed increase in labour's share must be interpreted as the result of a temporary disequilibrium, i.e., that the economy is operating off of its labour demand curve at a point like $K$, so that the real wage has risen above labour's average product. A subsequent decline in labour's share, such as that observed for the EC in Figure 5 above, can then be interpreted as the result of lagged or partial adjustment that moves the economy from a point like $K$ to a point like $G$. 
The Unemployment - Productivity Tradeoff, Page 20

\section{AN EXAMPLE: THE MINIMUM WAGE}

The minimum wage provides the most straightforward example of a wage-setting shock that can simultaneously change the unemployment rate and the level of productivity. France and the U. S. differ along many dimensions, but three stand out from the perspective of this paper. First, French unemployment, which was previously well below the U. S. rate, climbed to exceed the U. S. rate in every year after 1983 (and to exceed the EC average in every year after 1988). The 1994 French unemployment rate of 12.6 percent exceeded by a wide margin the U. S. rate of 6.1 percent. ${ }^{10}$ Second, French productivity growth exceeded that in the U. S. during the $1979-92$ period, but by a much wider margin of 1.51 points per annum outside of manufacturing than the 0.25 margin of French superiority in manufacturing. ${ }^{11}$ Third, the effective minimum wage (SMIC) continued its slow upward creep in France during the 1980s, as shown in Figure 10, while in the U. S. the effective minimum wage had fallen from roughly the French level in the late 1960s to well under half of the French level after $1982 .^{12}$ This diagram understates the importance of the SMIC, since the proportion of the French work force covered by the SMIC is much higher than the equivalent proportion in the U. S. (Bazen-Martin, p. 214).

The labour market diagram in Figure 11 provides an analysis of an increase in the French real minimum wage and a decrease in the U. S. real minimum wage. Note that, to use the same labour market analysis provided in Figures 8 and 9, we define the minimum wage in real terms, that is, divided by the product price deflator, in contrast to the data plotted in Figure 10, which define the effective minimum wage in terms of the ratio of the 
The Unemployment - Productivity Tradeoff, Page 21

statutory minimum wage to nominal labour compensation. Since real labour compensation for low-paid workers grew in France much faster than in the U. S. during this period (see Figure 6 above), Figure 10 understates the divergence between the two countries in the real minimum wage.

In the theoretical labour market diagram of Figure 11, both economies are assumed to share the same wage-setting and labour-demand schedules, as well as the same total labour supply schedule. The economy is initially in equilibrium at point $A$, as in Figures 8 and 9 . Now let us introduce an increase in the French real minimum wage that is sufficient to raise the overall French real wage from $(W / P)_{0}$ to $(W / P)_{F}$. The economy moves to point $F$, and employment falls from $E_{0}$ to $E_{F}$. Assuming competitive labour markets and instantaneous adjustment, the marginal product of labour rises in France in proportion to the increase in the real wage.

A different interpretation is required for the decline in the effective minimum wage in the U.S. If the economy starts out in equilibrium at point $A$, then a decline in the minimum wage to the lower level $(W / P)_{U s}$ will be ineffective, since the minimum wage will be below the market-clearing wage. In this case, we would still observe a contrast between France and the U. S. represented by the difference between points $F$ and $A$; in France productivity would grow and employment would shrink relative to the U. S.

Another possibility is that the steady erosion of the real minimum wage in the U.S. has contributed to a downward shift in the wage-setting curve to a position like $\mathrm{W}^{s}{ }_{1}-$ this downward shift may have been partly due to other causes, such as the decline in U. S. union 
density. Such a downward shift in the wage-serting curve would reduce the U. S. real wage from $(W / P)_{0}$ to $(W / P)_{U S}$, shift the economy to point $S$ and boost employment from $E_{0}$ to $E_{U S}$. In this analysis, the divergent behavior of the real minimum wage can help to explain the divergent behavior of both unemployment and productivity in France and the $U$. S. in the 1980s.

Beyond affecting the evolution of unemployment and productivity, what would be the other major effects of the divergence in effective minimum wages depicted in Figures 10 and 11? The real earnings of low-paid French workers would be boosted and those of lowpaid American workers would be depressed, thus helping to explain the contrast between an income dispersion that widened in the U.S. in the 1980 s while remaining roughly constant in France (Figure 6 above). If there were no unemployment compensation system, there would be an increased dispersion in incomes between the employed French, now making more, and the unemployed, now making zero. But in the extreme case of an unemployment compensation system with a 100 percent replacement ratio (ignoring taxes), an increase in the real minimum wage would raise the welfare not only of the employed but of the unemployed as well. The French government would be obliged to pay out extra unemployment compensation shown in Figure 11 by the rectangle $F J E_{0} E_{F}$. This amount takes the form of a transfer to the current unemployed from some combination of current workers and future generations of taxpayers. ${ }^{13}$

If the labour demand curve in Figure 11 had a unitary elasticity, then labour income (and labour's income share) would be the same at points $A$ and $F$. With full-replacement 
unemployment compensation, the most obvious effect would be to create an increase in government transfer expenditures as a share of GDP, with possible side effects in the form of higher taxes or a higher public debt-GDP ratio, which in the latter case might lead as well to higher real interest rates. Another effect, often discussed in connection with the hysteresis hypothesis, would be an erosion of the skills of the newly unemployed $\left(E_{0}-E_{F}\right)$. Ironically, measured national productivity could increase while the skills of the population deteriorate, because a decrease in the employment-population ratio would be accompanied by a decline in the skills of the unemployed.

\section{Literature on the Effects of the Minimum Wage}

There is a contradiction between the analysis of Figure 11 and the recent literature on the effects of the minimum wage. Studies like those of Bazen-Martin (1991) for France, Dickens et. al. (1993) for the U. K., and Card (1992), Card-Katz-Krueger (1993), CardKrueger (1994), and Krueger (1994) for the U. S., all seem to indicate that the minimum wage has small or negligible effects on employment. These results occur despite findings that minimum wages "spill over" to other wages, for instance the finding by Bazen-Martin (1991) that a one percentage-point increase in the real value of the SMIC increases the real value of real youth earnings by 0.4 of a percentage point.

There are at least two interpretations of the small measured employment effects of changes in the minimum wage. An equilibrium interpretation is that the labour demand curve in Figure 11 is extremely steep, accounting for the absence of employment effects in the studies cited above. Under this interpretation an increase in the minimum wage is an 
excellent way to boost productivity with minimal employment effects. However, one doubts that the hypothesis of a near-vertical long-run labour demand curve can be supported, as this would conflict with a large production function literature supporting an elasticity of substitution in the range of 0.5 to 1.0 (Bean, 1994, p. 614), and with the long-run constancy of labour's share that is consistent with an elasticity of 1.0. Indeed, Bazen-Martin (1991, p. 215) "believe it to be the case" that an increase in real youth labour costs have reduced youth employment, despite their inability to establish this response "satisfactorily."

An alternative view is that the short-run response is small while the long-run response is large, i.e., that the process of substitution caused by a significant increase in the minimum wage (or any other shock to the wage-setting curve) takes a significant time to occur. In this interpretation the labour demand curve gradually rotates through time, starting steep and becoming flatter, and this lagged adjustment process is inadequately captured in studies that focus on short-run responses.

The same problems may affect the studies of the U.S. minimum wage by Card and his co-authors. These studies found no adverse employment effects following increases in the minimum wage above the Federal level in particular states of the U. S. But there is a different problem as well. It is very likely that by 1990 the U. S. minimum wage had dropped so low as to be ineffective, that is, to be below the market-clearing wage rate like point $A$ in Figure 11. The U.S. studies cited here focussed on increases in the minimum wage from a low level, and if at this level the minimum wage was ineffective, then it is no surprise that no employment effects could be found. 
Finally, even when academic studies fail to provide convincing demonstrations of effects that seem theoretically plausible, anecdotal evidence seems compelling that the divergent evolution of the French and American minimum wages plotted in Figure 10 has resulted in very different employment practices, particularly in the service sector. American supermarkets (often in some places, always in others) employ two people at each check-out lane, one to ring up the purchases and the other to place the purchases in bags. French supermarkets expect customers to bag their own groceries and sometimes to provide their

own bags. Similarly, American restaurants, from the high-priced gourmet level down to mid-level, employ "busboys" to set and clear tables (these are often recent legal or illegal immigrants) while "waitpeople" take orders and serve food. In contrast, in much of Europe staffing levels in restaurants are noticeably lower, and waitpeople set and clear tables in addition to taking orders and serving food.

\section{MECHANISMS}

As we have seen, a positive correlation between unemployment and the level of productivity can be generated by any factor that shifts the wage setting curve, and this correlation can persist for as long as it takes for the capital stock to adjust. In this section we distinguish those variables that shift the wage-setting schedule and cause movements along the UPT schedule of Figure 7 from those other factors that may cause changes in productivity or in unemployment without simultaneously changing both; these cause shifts in Figure 7's UPT schedule. 
The Unemployment - Productivity Tradeoff, Page 26

\section{Shifts in the UPT Schedule}

First we translate the preceding labour-market analysis in terms of the UPT schedule, which reappears in Figure 12. Recall from our discussion of Figure 7 that movements in MFP and in capital relative to a fixed level of employment and unemployment cause shifts in the UPT schedule, while changes in employment and unemployment occurring with a fixed level of MFP and capital input cause movements along the UPT schedule.

The economy begins at point $A$ in Figure 12, the same situation of initial equilibrium as at point $A$ of Figure 8 , where the initial unemployment rate is $U_{0}$. Next, an adverse wage-setting shock shifts the economy to point $B$, as in Figure 8, with a higher marginal and average product of labour and a higher unemployment rate $U_{1}$. The initial $U P T_{0}$ schedule drawn between points $A$ and $B$ in Figure 12 shows that over the period of time encompassed by situations $A$ and $B$, the unemployment rate increases by the amount $U_{1}-U_{0}$, while growth in productivity (output per employee) is boosted above whatever rate prevailed at point $A$.

In the long run there will be a period of disinvestment that, as shown in Figure 8, reduces productivity and the real wage to the original level at point $C$ while further boosting the unemployment rate from $U_{1}$ to $U_{2}$. The same situation is shown in Figure 12 by the downward shift in the UPT schedule to $U P T_{1}$. A point like $C$ depicts the cumulative change from the initial equilibrium situation at point $A$. There is a cumulative change in unemployment $\left(U_{2}-U_{0}\right)$, while productivity growth is unchanged from the initial situation at point $A$. Thus one conclusion from this analysis is that the process of capital accumulation implies that in the long-run the UPT schedule becomes flat or even horizontal, 
as implied by the horizontal schedule $U P T_{L R}$.

The movements in Figure 12 from point $A$ to $B$ to $C$ are caused by a wage-setting shock followed by capital decumulation. Other factors that might shift the UPT schedule in an unfavorable (downward) direction include an adverse oil price shock, while better education or an exogenous improvement in the rate of innovation would shift the UPT schedule in a favorable (upward) direction. Figure 12 suggests that we might fruitfully distinguish those causes of higher European unemployment that can be interpreted as initially causing a northeast movement along the UPT schedule from those that can be interpreted as causing shifts in that schedule. Similarly, we might investigate the suggested causes of slow productivity growth and increased inequality in the United Statc by applying the same distinction involving movements along vs. shifts in the UPT schedule.

\section{Sources of Upward Shifts in the Wage-Setting Schedule}

Bean (1994, pp. 579) interprets the wage-setting mechanism in terms of this equation:

$$
w-p^{e}=-\gamma_{1} U+\left(1-\gamma_{2}\right)(w-p)_{-1}+Z_{w} \Gamma+\epsilon_{w},
$$

where lower-case letters are logs, $w$ is the $\log$ wage, $p$ is the $\log$ price, $U$ is the unemployment rate, and $Z_{w}$ is a vector of variables "that includes the reservation wage and whatever factors are thought to influence the markup over the reservation wage." Thus any element in $Z_{w}$ may in principle be a source of a shift in the wage-setting schedule and at the same time a source of a movement along a given UPT schedule. 
The typical European list of elements that would shift $Z_{w}$ upward (drawn from Bean, pp. 587-96) includes the following.

1. A higher minimum wage, as discussed previously.

2. An increase in the level and/or coverage of unemployment benefits, which raise the effective replacement ratio of the unemployment benefits system and hence the reservation wage. ${ }^{14}$

3. An increase in the price wedge. Since firms care about the product-price real wage and workers care about the consumption-price real wage, any increase in consumer prices relative to product prices would shift up the wage-setting schedule. An increase in this wedge occurred at the time of the first oil shock, which also marks the beginning of the productivity growth slowdown. An increase in the price wedge can also be caused by a decline in the terms of trade that raises import prices relative to the prices of domestic production.

4. An increase in the tax wedge. Since firms pay pre-tax wages but workers receive after-tax wages, any increase in payroll or income taxes can shift up the wage-setting schedule. Tax wedges in Europe range from 40 to 70 percent, in contrast to a range of 20 to 25 percent in the U. S. and Japan. ${ }^{15}$

5. An increase in worker militancy. An increase in union power would shift up the wage-setting schedule, raising both unemployment and productivity. Trade union membership as a share of the labour force is only 15 percent in the U. S. but is much higher in most European countries, in the 30-40 percent range in Germany, Italy, and Britain, and 
80 percent in Sweden (France is an exception with a share below that of the U. S.). One problem with this explanation is that, while relatively high, the trade union membership share fell in most European countries in the 1980s (primarily as a result of the growing share of employment in the service sector).

\section{Factors which May Shift the UPT Schedule}

Numerous other factors have been cited as causes of high European unemployment, but these do not involve causation going initially from wage-setting behavior to subsequent responses by productivity and the unemployment rate. Hence they are best interpreted as factors causing an adverse (downward) shift in the UPT schedule of Figure 12.

6. Supply shock combined with real wage rigidity. As in Figure 9, an adverse supply shock (e.g., a higher real price of oil) can simultaneously cause unemployment to rise and productivity to fall, thus shifting the UPT schedule downward. The dichotomy between real wage rigidity and real-wage flexibility determines where the economy winds up on the lower UPT schedule, so that the position of Europe might be interpreted as similar to point $C$ on the lower UPT schedule of Figure 12, and that of the U. S. at a point like $H$.

7. Mismatch. A shift in technology may create unemployment if there are barriers to labour mobility across occupations, regions, and industrial sectors. An increased pace of technological change or growing openness to foreign trade might increase structural unemployment without causing a change in productivity, either up or down. Thus mismatch can be interpreted as shifting the UPT schedule to the right, i.e., down.

8. Labour market regulations. Numerous forms of employment regulation lead to 
the general diagnosis that European labour markets are more "rigid" than in the U.S. The exhaustive analysis of Grubb and Wells (1993) includes among these regulations restrictions on employers' freedom to dismiss workers; limits on the use or the legal validity of fixed-term contracts; limits on the use of temporary work; restrictions on weekly hours of regular or overtime work; and limits on use of part-time work. Also included in this category is mandated severance pay. Here the important point is that when aggregate demand is high, such regulations can stabilize employment and reduce the incidence of temporary layoffs in response to mild recessions. But when a major decline in demand occurs, perhaps amplified by an upward shift in the wage setting schedule for the reasons outlined above, such regulations can stabilize unemployment by raising the present discounted value of the cost to employers of hiring an extra worker in response to an upturn in demand. ${ }^{16}$ Again, such regulations may increase unemployment without necessarily changing productivity and should be interpreted as causing a rightward shift in the UPT schedule.

9. Product market regulations. A particular form of regulation that potentially boosts both unemployment and productivity is the draconian type of shop-closing rules imposed in Germany and some other countries. A movement to Sunday and evening opening, underway currently in Britain, clearly creates jobs but reduces retailing productivity by spreading the same transactions over more labour hours. While such regulations push unemployment and productivity in the same direction as a wage-setting shock, there is no reason why the mix of unemployment and productivity responses should trace out a labour 
demand curve, and hence we treat such regulations as shifting the UPT schedule rather than causing a movement along it.

\section{Sources of Slow Productivity Growth and Increasing Inequality in the U. S.}

Bean effectively criticizes much of the research attributing the rise in European unemployment to particular items on the above list and concludes that there must be multiple causes, rather than a single cause. Can we identify some of the above items as promising explanations by comparing behavior in the U.S. and Europe? While the replacement ratio of unemployment benefits (item \#2 on the above list) changed little in either the E. C. or in the U. S. between the late 1960s and late 1980s, the fraction of U. S. employees eligible for benefits has fallen substantially. While the price wedge (\#3) behaved similarly in the E. C. and U. S., the tax wedge (\#4) in the E. C. is both higher and increased more between the late 1960s and late 1980s (Bean, 1993, p. 586). The rigid real wage hypothesis (\#6) seems consistent with the observed bulge in the E. C. labour share between 1974 and 1982 (Figure 5 above). While there is no reason for mismatch (\#7) to have differed between Europe and the U. S., there is clearly a major difference between the U. S. and particular European countries in the extent of labour market and product market regulation (\#8 and \#9).

Perhaps the leading candidate for causing divergent behavior across the Atlantic is the marked decline in U. S. union membership (\#5), from 26.2 percent in 1977 to 15.8 percent in 1993 (union members as a fraction of wage and salary workers). Together with the sharp reduction in the real minimum wage (\#1), this decline in union representation plausibly 
exerted downward pressure on the U.S. wage setting schedule throughout the 1970s and 1980s. The result was the well-known dichotomy between rapid growth in U.S. employment relative to Europe (Figure 2 above), but a less widely recognized implication is that some part of the continuing productivity growth divergence must have occurred as well.

In addition to unions and the minimum wage, any U.S. list of factors causing depressed real wages and productivity must include immigration and imports. Annual legal immigration as a percent of the population has steadily increased in each decade of the postwar period (Simon, 1991), although this percentage is still far below the records set during 1890-1914 (also a period of slow productivity growth). In addition, a large and undetermined amount of illegal immigration has added substantially to the supply of unskilled labour and plausibly added to downward pressure on the wage-setting schedule. Finally, Johnson and Stafford (1993) have argued convincingly that an increased supply of medium-technology goods from newly industrializing countries can cause an absolute decline in the real wage of an advanced country (or group of countries) that previously had a monopoly on the manufacturing of those goods. To the extent that the U.S. was more open to Asian imports than some European countries that imposed quantitative trade restrictions (notably France and Italy), imports of goods can put the same kind of downward pressure on the wage-setting schedule as imports of people, i.e., immigration. 
The Unemployment - Productivity Tradeoff, Page 33

\section{PRODUCTIVITY MEASUREMENT}

Two issues arise in making international productivity comparisons, data availability and measurement differences. The most accessible source of productivity data by sector, the OECD Intersectoral Database (ISDB), measures productivity as output per employee rather than output per hour. Since hours per employee have declined much more rapidly in most European countries than in the U. S., the productivity growth differential between Europe and the U.S. is understated by differences in output per employee. This study has developed a new data file on output, hours, capital input, output per hour, and MFP from national sources for the U. S. and from OECD and other data on the other six members of the G-7. For the "other six," data were obtained on hours per employee in the total private economy and in manufacturing, and hours per employee in the rest of the economy were derived as a residual. Hours per employee in each sector in non-manufacturing were set equal to this derived residual. ${ }^{17}$

is for the second problem, measurement issues, Gordon-Baily (1991) have argued that productivity growth in manufacturing in the U.S. tends to be overstated relative to other countries while in nonmanufacturing tends to be understated. The problem in manufacturing is the use of a hedonic price index for computer output that declines very rapidly (20-25 percent per annum), together with a single base year for the real GDP accounts that results in understating the importance of computers prior to the 1987 base year (i.e., weighting them with their 1987 prices that are low relative to pre-1987) and overstating the importance of computers after the 1987 base year (i.e., weighting them with 
their 1987 prices that are high relative to post-1987). This procedure tends to understate productivity growth in U. S. manufacturing before 1987 and overstate it since 1987.

For non-manufacturing Gordon-Baily provide a number of examples to suggest that U. S. productivity growth may be understated relative to other countries. For instance, the U. S. still uses labour input as a proxy for output (i.e., defines away productivity change) in banking and finance, and it uses peculiar procedures to measure output in industries like insurance. Output measures in the U. S. construction industry are also highly suspect; measured U.S. construction productivity measured as a ratio to Canadian construction productivity has fallen by two-thirds since 1965 . Here we will of necessity take the productivity data at face value. Estimating the importance of measurement differences across countries is a difficult and ongoing research project.

\section{PRODUCTIVITY GROWTH DIFFERENCES ACROSS COUNTRIES AND SECTORS}

The growth rates of output per hour and of MFP for seven countries, nine sectors, and three alternative aggregates (private, private nonfarm, and private nonfarm nonmanufacturing nonmining) are provided in tables available from the author. Also available are tables showing levels of output per hour for each sector in 1992, converted into dollars at OECD 1992 exchange rates.

\section{Means and Variances of Output per Hour Growth Rates}

Some of the main features of the data are summarized in Table 2, which displays in 
The Unemployment - Productivity Tradeoff, Page 35

the top frame unweighted means and variances across the nine sectors for each of the seven countries, and in the bottom frame unweighted means and variances across the seven countries for each of the nine sectors. The averages show the now familiar post-1973 slowdown and indicate that post-1973 productivity growth for all countries averaged together was about the same in 1973-79 as in 1973-92. This would appear to rule out the energy price shocks as a major causative factor.

Every country experienced a post-1973 slowdown, but some (U. S., Canada and Japan) did better during 1979-92 than 1973-79, while the four European countries all experienced slower productivity growth after 1979 than during 1973-79. The bottom section shows that every sector experienced a post-1973 slowdown. In agriculture, mining, and construction, productivity growth was more rapid after 1979 than during 1973-79, while for manufacturing and trade there was no difference, and for transport/communication, FIRE, and services, there was a further slowdown after 1979.

Is productivity growth more variable across countries or across sectors? The variances across countries within given sectors are averaged with and without mining, because of the huge variance of mining (including oil production) productivity during the oil shock period, 1973-79. Comparing the first (1960-73) and last (1979-92) periods, the variance across sectors for given countries was smaller than the variance across countries for given sectors in the earlier period, whereas the reverse was true in the latter period. The relatively low cross-country within-sector variance during $1979-92$ suggests that technological convergence may have played a role in causing rapid productivity growth outside the U. S. prior to 1973 
or 1979 , followed by more modest rates as individual sectors neared the frontier achieved by American technology.

\section{What did Capital Contribute to the Productivity Slowdown?}

Our theoretical analysis treats MFP growth as exogenous. The growth rate of output per hour relative to MFP growth can be affected by wage-setting shocks that boost real wages and productivity, or by subsequent disinvestment that reduces real wages and productivity.

The relation between growth in output per hour and in MFP is defined in equation (2) above, which is repeated here:

$$
\Delta q-\Delta h=\Delta a+(1-\alpha)(\Delta k-\Delta h) .
$$

Thus the growth rate of output per hour $(\Delta q-\Delta h)$ is simply the growth rate of MFP $(\Delta a)$ plus the contribution of the growth in capital per hour $[(1-\alpha)(\Delta k-\Delta h)]$.

Table 3 decomposes the observed growth rate of output per hour for the nonfarm business sector in the G-7 countries between the separate contributions of capital and MFP. For most countries all three columns reveal a slowdown in growth rates between the first period (1960-73) and the final period (1979-92), but there are some anomalies. Between the first and last periods the capital contribution actually accelerates in both the U. S. and Canada, and consequently the slowdown in MFP growth is greater than in the growth rate of output per hour. Table 3 also reveals that for $1979-92$ the excess of growth in output per hour for Europe versus the U. S. is more than explained by MFP growth, with little 
contribution of capital for France and Germany, and a negative contribution of capital for Italy and the $\mathrm{U} . \mathrm{K}$.

The contribution of capital growth to the slowdown in growth in output per hour is exhibited in Table 4 not just for nonfarm private business, but also for manufacturing and a large "residual" sector, private nonfarm nonmanufacturing nonmining (PNFNMNM). Here we note that the contribution of capital to the slowdown in all three sectors is negative for both the U. S. and Canada, while it is positive in the four European countries (except for manufacturing in Italy, where there is a negative contribution of capital to the slowdown in growth of output per hour, and for U. K. manufacturing, where there is no slowdown in the growth of output per hour but rather an acceleration).

There is some support in Tables 3 and 4 for the relationships suggested in this paper. For the aggregate economy (the nonfarm economy displayed in Table 3 and the first three columns of Table 4), there was a very substantial slowdown in the contribution of capital in Europe but not in the U.S. This supports the emphasis placed above on the role of wage-setting shocks in setting into motion a process of capital decumulation, while also causing an increase in unemployment. A notable exception is provided by Canada, where the contribution of capital accelerated rather than slowed down, while Canadian unemployment increased between 1960-73 and 1979-92 almost as much as in the four large European economies. 


\section{Productivity Growth Regressions}

The paper has examined the dynamic interaction of unemployment and productivity. It has shown that the correlation between unemployment and productivity can be positive, zero, or negative, and the same carries over to the correlation between the change in unemployment and the growth rate of productivity.

However, the above analysis makes a definite prediction about at least one correlation, that there should be a negative correlation between the change in unemployment and the change in capital per member of the labour force. To the extent that increased unemployment is initially caused by a positive wage-setting shock, we should observe a decline in capital relative to the labour force (or relative to the initial level of employment).

To examine these interrelations, we run a set of regression equations in which the dependent variables are alternatively growth in output per hour, growth in capital per member of the labour force, and growth in MFP. Each variable is measured as the growth rate for a particular country and sector over the three time intervals shown in Tables 2 and 3, that is, 1960-73, 1973-79, and 1979-92. The explanatory variables are a set of dummy variables for country effects, sector effects, time effects, as well as two economic variables. First, in common with numerous recent studies of the convergence process, we include the level of productivity in a given country-sector relative to that for the U. S. in the same sector at the beginning of a particular interval. The coefficient on this relative level variable should be negative, indicating that country-sectors with a low initial level of productivity grow relatively rapidly. Second, we include the change in a country's unemployment rate over 
each time interval, since our above analysis relates the level of the unemployment rate to the level of productivity, or the change in the unemployment rate to the growth rate of productivity.

Thus the regression equation is:

$$
(\Delta q-\Delta h)_{i k t}=\alpha_{0}+\alpha_{1} \Delta U_{k t}+\alpha_{2} \frac{(Q / H)_{i k r}}{(Q / H)_{i t U s}}+\Sigma \beta_{k} D C_{k}+\Sigma \gamma_{i} D S_{i}+\Sigma t D T_{t}+\epsilon_{i k t}
$$

Here DC is a set of country dummies (with the US taken as the base), DS is a set of sector dummies (with manufacturing taken as the base), and $D T$ is a set of time interval dummies (with 1960-73 taken as the base).

The results are presented in Table 5. The equation explaining the growth rate of output per hour is presented three times in columns (1)-(3). The first two columns differ only in that (1) excludes the country-sector level effect. Inclusion of this effect in (2) substantially reduces the size of the country dummies, indicating that part of the more rapid productivity growth in the European countries relative to the U. S. can be attributed to the convergence effect. Inclusion of this effect in (2) has no impact on the unemployment change coefficient, which is negative but insignificant in both columns (1) and (2). Exclusion of this variable in column (3) further reduces the size of the country effects, indicating that the high values of the country effects in columns (1) and (2) are in part offsetting the negative coefficient on the change in unemployment for the European countries. Several sector dummies are highly significant, indicating that across all countries 
productivity growth is significantly slower in construction and FIRE than in manufacturing (the base sector). Interestingly, exclusion of the unemployment variable in column (3) yields a highly significant slowdown coefficient on the 1979-92 time effect; in columns (1) and (2) the productivity slowdown is spuriously explained by the increase in unemployment.

In column (4) the dependent variable is capital per potential hour, where potential hours is defined as the hours that would have been worked if a country had the unemployment rate at the beginning of the period rather than at the end of the period. Here the country-sector productivity level effect is again highly significant, and the change in the unemployment rate has the expected negative sign at a significance level of 5 percent. $^{18}$ Country-specific dummy variables for the four European countries are positive and significant, indicating that a substantial part of the productivity growth advantage of several European countries is explained by their more rapid rate of capital accumulation (holding constant the change in their unemployment rates). The pattern of sector-specific dummy coefficients is somewhat different, with mining experiencing unusually rapid capital accumulation and FIRE experiencing unusually slow capital accumulation. Somewhat unexpectedly, there are no time-specific slowdown effects, indicating that whatever slowdown in capital accumulation has occurred is entirely explained by the country-sector productivity level variable and by the change in unemployment.

Finally, column (5) presents the same regression with the change in MFP as dependent variable. Here the country-specific effect is significant only for Italy. Thus it appears that most of the productivity advantage of France, Germany, and the U. K. over the 
U. S., so evident in column (1), can be explained by convergence and capital accumulation. Significantly negative sector-specific effects are now present for MFP growth in agriculture, mining, construction, FIRE, and services (again, relative to manufacturing). The timespecific dummy coefficients indicate that between two-thirds and three-quarters of the productivity slowdown in column (3) can be attributed to a slowdown in MFP growth, and the rest can be attributed to a slowdown in capital accumulation associated with higher unemployment.

To summarize, we find that much of the productivity growth advantage of Europe countries over the United States is explained by convergence and more rapid capital accumulation. Only for Italy does more rapid growth in MFP explain a significant part of the productivity growth differential. The element of our theoretical analysis that is validated by the regression results concerns the growth of capital per potential hour, which seems to have decelerated more in countries with larger increases in unemployment. The theoretical analysis showed that productivity could be either positively or negatively correlated with unemployment in a world exposed to a mixture of wage-setting shocks and oil-price shocks, and so it is not surprising that the regressions do not identify a significant correlation between productivity (output per hour or MFP) and unemployment.

\section{CONCLUSION}

The point of departure for this paper is the divergence between the concerns of European and American economists. The persistence of high unemployment dominates 
European policy discussions, whereas American economists are increasingly concerned with the slow growth rate of real wages and a large increase in the dispersion of incomes. This paper argues that these phenomena may be more closely related than is commonly recognized. The many factors that are believed to have contributed to European unemployment by shifting upward the European wage-setting schedule may also have increased the growth rate of European productivity relative to that in the U.S.

However plausible the notion that wage-setting shocks can create a positive correlation between unemployment and productivity, that relation is likely soon to be eroded by changes in the rate of capital accumulation. We find that countries with the greatest increases in unemployment had the largest slowdowns in the growth rate of capital per potential labour hour, a correlation that is consistent with the important role that capital accumulation plays in our analysis. Europe entered the 1990s with much higher unemployment in the U.S. but with approximately the same rate of capacity utilization, indicating that there was no longer sufficient capital to equip all the employees who would be at work at the unemployment rates of the late 1970 s.

The raw numbers show substantially more rapid growth in output per hour in the four large European countries than in the U. S. Our empirical analysis shows that none of this is related to the large increase in unemployment in Europe between the 1960s and the 1980s. Instead, faster productivity growth in Europe mainly reflects the convergence effect, i.e., that Europe started at a lower level of productivity and gradually converged toward the U. S. level, and the impact of more rapid capital accumulation. The fact that European 
productivity growth slowed down more than that in the U.S. is attributed both to the gradual weakening of the convergence effect and also to the negative impact of wage-setting shocks which both increased the unemployment rate and reduced the growth rate of capital per potential labour hour. 


\section{REFERENCES}

Alogoskoufis, George S., and ManNing, Alan (1988). "On the Persistence of Unemployment," Economic Policy 7 (October), pp. 427-469.

Baily, Martin N. AND Gordon, Robert J. (1988). "The Productivity Slowdown, Measurement Issues, and the Explosion of Computer Power," Brookings Papers on Economic Activity, 19 (no. 2), pp. 347-420.

Baumol, William J., Blackman, Sue AnNe Batey, and Wolff, Edward N. (1989). Productivity and American Leadership: The Long View (Cambridge MA: MIT Press). Bean, Charles R. (1994). "European Unemployment: A Survey," Joumal of Economic Literature, 32 (June), 573-619.

Bernard, ANdrew B. AND Jones, Charles I. (1994). "Comparing Apples to Oranges: Productivity Convergence and Measurement across Industries and Countries." CEPR (Stanford) discussion paper 389, March.

BlanChard, Olivier J. (1990). "Unemployment: Getting the Qustions Right - and Some of the Answers," in Jacques H. Drèze and Charles R. Bean, eds., Europe's Unemployment Problem (Cambridge MA: MIT Press), 66-89.

Bosworth, BARRY, AND PeRry, GeORGe L. (1994). "Productivity and Real Wages: Is There a Puzzle?" Brookings Papers on Economic Activity, 25 (no. 1), pp. 317-44.

Branson, William H. AND Rotemberg, Julio J. (1980). "INTERNATIONAl AdJuSTMENT WITH WAGE RIGIDITY," European Economic Review, 13 (May), pp. 309-32. Bruno, Michael, AND SACHS, JeFFrey D. (1985). Economics of Worldwide Stagflation 
(Cambridge MA: Harvard University Press).

CARD, David (1992). "Do Minimum Wages Reduce Employment? A Case Study of California 1987-89" Industrial and Labor Relations Review, 46, pp. 38-54. AND Krueger, Alan B. (1994). "Minimum Wages and Employment: A Case Study of the Fast Food Industry in New Jersey and Pennsylvania,' American Economic Review, 84 (September), pp. 772-93. , KATZ, LAwRENCE F., AND KRUEGER, Alan B. (1993). "An Evaluation of Recent Evidence on the Employment Effects of Minimum and Subminimum Wages," NBER working paper no. 4528 , November.

Crafts, Nicholas (1992). "Productivity Growth Reconsidered," Economic Policy 15 (October), pp. 387-426.

Dickens, Richard, Machin, Stephen, and ManNing, Alan (1993). "The Effects of Minimum Wages on Employment: Theory and Evidence from the U. K.", discussion paper from LSE CEP (October).

Elmeskov, Jørgen, and MacFarlan, Maitland (1993). "Unemployment Persistence," OECD Economic Studies (no. 21, Winter), pp. 57-88.

FranZ, Wolfgang, and Gordon, Robert J. (1993). "Wage and Price Dynamics in Germany and America: Differences and Common Themes," European Economic Review, 37 (May), pp. 719-54.

FreEMAN, Richard B. (1994). "How Labor Fares in Advanced Economies," in R. B. Freeman, ed., Working Under Different Rules (New York: Russell Sage Foundation), 
pp. 1-28.

Gordon, Robert J. (1993). "The Jobless Recovery: Does It Signal a New Era of Productivity-Led Growth?" Brookings Papers on Economic Activity, 24 (no. 1), pp. 271-316.

AND BAILY, MARTIN N. (1991). "Measurement Issues and the Productivity

Slowdown in Five Major Industrial Countries," in G. Bell, ed., Technology and Productivity: The Challenge for Economic Policy (Paris: OECD), pp. 187-206.

JOHNSON, GEORGE E. AND STAFFORD, FRANK P. (1993). "International Competition and Real Wages," American Economic Review Papers and Proceedings, 83 (May), pp. 127-30. Krueger, Alan B. (1994). "The Effect of the Minimum Wage When it Really Bites: A Reexamination of the Evidence from Puerto Rico," NBER working paper no. 4757, June.

Krugman, Paul R. (1987). "Slow Growth in Europe: Conceptual Issues," in R. Z. Lawrence and C. L. Schultze, Barriers to European Growth: A Transatlantic View (Washington DC: The Brookings Institution), pp. 48-75.

LAYARD, Richard, NiCKell, STEPHEN, AND JACKMAN, Richard (1991). Unemployment: Macroeconomic Performance and the Labor Market (Oxford: Oxford University Press).

LINDBECK, ASSAR (1994a). "The Welfare State and the Employment Problem," Stockholm, Institute for International Economic Studies, Seminar Paper No. 561, January. (1994b). "The Unemployment Problem," Stockholm, Institute for International 
The Unemployment - Productivity Tradeoff, Page 47

Economic Studies Seminar Paper No. 575, July.

SACHS, JefrReY D. (1979). "Wages, Profits, and Macroeconomic Adjustment: A Comparative Study," Brookings Papers on Economic Activity, 10 (no. 2), pp. 269-319. SAINT-PAUL, GILles (1994). "Searchin for the Virtues of the European Model," CEPR working paper no. 950, May.

SimON, Julian L. (1991). "The Case for Greatly Increased Immigration," The Public Interest (Winter, no. 102), pp. 89-103. 


\section{FOOTNOTES}

1. See, for instance, Bean (1994, pp. 587-88), Blanchard (1990, p. 72), and Layard et. al. (1991, pp. 169-70). The Bazen-Martin (1991) analysis of the French minimum wage also takes productivity growth as exogenous (see esp. p. 211).

2. An exception is Freeman (1994, p. 14), who includes one paragraph suggesting that "The evidence that the United States has done better than Europe in employment growth but worse in growth of real wages and productivity suggests that perhaps these are two sides of the same coin." However, this idea is not explored further. Lindbeck (1994b, p. 3) states in passing that "the United States may be regarded as having 'paid' for its successful employment performance by slow productivity growth and stagnating real wages."

3. Saint-Paul (1994) is a particularly articulate and convincing example.

4. By December, 1994, the U. S. unemployment rate had declined to 5.4 percent, close to the 1989 annual average of 5.3 percent.

5. A general introduction to the convergence issue is provided by Baumol et. al. (1990), Chapters 5 and 9. More recent evidence, with particular emphasis on the U. K., is provided by Crafts (1993). The important role of convergence in explaining the divergence between U. S. and European productivity growth rates is validated below in Table 5 .

6. See Bernard and Jones (1994). Two reasons for the discrepancy are that 
Bernard and Jones make no adjustment for hours (thus basing their comparisons on output per employee), and also they use PPP price comparisons for 1980 rather than the 1992 figures underlying Table 1.

7. This section provides a bare-bones graphical discussion of a model developed in more detail by Alogoskoufis and Manning (1988), Blanchard (1990), Bean (1994), and Layard et. al. (1991).

8. Consider a Cobb-Douglas production function $Y=A H^{\alpha} K^{1-\alpha}$, the same as equation (2) in the text (where the latter is converted into logs). The marginal product of labor and the real wage are equal to $\alpha Y / H$ and the marginal product of capital is equal to $(1-\alpha) Y / K$. Designating the initial equilibrium situation at point $A$ with asterisks, the wage-setting curve is $w=\alpha(1+\underline{\lambda})\left(Y^{*} / H^{*}\right)\left(H / H^{*}\right)^{\gamma}$, where at point $A$ the "wage push" parameter $(\underline{\lambda})$ is initially set at zero. A hypothetical "wage push" of three percent $(\lambda$ $=.03$ ) pushes the economy from point $A$ to point $B$, and assuming $\alpha=0.75$ and $\gamma=0.5$, we can calculate that there will follow at point $B$ an increase in the real wage of 1 percent and a decline in labor input of 3.9 percent. Once we allow subsequent disinvestment that decreases the capital stock, and if the capital stock continues to adjust until the marginal product of capital is equal to a fixed supply price of capital, then output, labor input, and capital input must all decline in proportion, so that the $\mathrm{Y} / \mathrm{H}$ and $\mathrm{Y} / \mathrm{K}$ ratios return to their original values. With the assumed parameters of the wage setting curve, this requires a decline in output and factor inputs of 5.8 percent at point C. 
9. If MFP is defined as output relative to the weighted inputs of not just labor and capital but also energy, then MFP remains constant and the entire cause of the downward shift of the schedule $N^{D}$ is the reduced quantity of energy. However, if as in the empirical research in this paper, MFP is calculated relative to the weighted inputs of just labor and capital input, then MFP is lower along schedule $N^{D}{ }_{2}$ than along schedule $N^{D}{ }_{0}$

10. These comparisons refer to the official U. S. 1994 unemployment rate and the projection of the French 1994 unemployment rate, OECD Economic Outlook, December 1994, Annex Table 54, p. A58.

11. The French and U. S. output per hour growth rates for 1979-92 are, respectively, 2.14 and 0.63 percent per year in private nonfarm nonmanufacturing nonmining, and 2.85 and 2.50 percent per year in manufacturing.

12. Note that the data in Figure 9 use the Bazen-Martin (1991) data for France but not for the U.S. The denominator for the U.S. minimum wage used by BazenMartin, that is, average hourly earnings for nonfarm private production workers, is well known to be biassed downward quite severely as a measure of the growth of nominal compensation (see Bosworth-Perry 1994). In Figure 9 we use as a denominator average hourly compensation.

13. Saint-Paul $(1994$, p. 3$)$ argues that "an increase in the minimum wage may well have adverse impacts on inequality. This is because while it redistributes income from the skilled to the unskilled workers, by creating unemployment it also redistributes income from the poorest to the lower-middle class." This argument appears to neglect 
the unemployment compensation received by those who lose their jobs as a result of a higher minimum wage.

14. See Lindbeck (1994b, p. 1), "It is a commonplace that very generous unemployment benefits with long, or even unlimited duration and with lax work tests contribute to unemployment persistence."

15. Lindbeck (1994b), p. 9.

16. See Lindbeck (1994a), pp. 2-3.

17. Bernard-Jones create a hybrid measure of MFP, based on a weighted average of output per employee and output per unit of capital. By ignoring changes in hours per employee, all their measures understate differences in productivity growth between Europe and the U. S.

18. If the growth rate of capital per potential hour is replaced by the growth rate of capital per actual hour, the coefficient on the change in unemployment declines from -0.56 to -0.47 , and the significance level changes from 5 percent to about 9 percent. 


\section{TABLE 1}

Three Measures of Convergence for the G-7, 1991

\begin{tabular}{|lccc||}
\hline Country & GDP per capita & GDP per employee & GDP per hour \\
\hline United States & 100 & 100 & 100 \\
Canada & 89 & 89 & 92 \\
Japan & 87 & 78 & 69 \\
France & 83 & 96 & 102 \\
Germany & 89 & 90 & 102 \\
Italy & 77 & 96 & 96 \\
United Kingdom & 74 & 76 & 85 \\
\hline
\end{tabular}

Source: Freeman (1994), Table 1.1, pg. 9. Hours per employee from our data set described in the data appendix. 
TABLE 2

Growth Rates of Output per Hour, Mean and Variance by Country and Sector

\begin{tabular}{||lccc||}
\hline Country & $1960-73$ & $1973-79$ & $1979-92$ \\
\hline United States & $2.15(3.99)$ & $-0.95(13.83)$ & $2.01(3.93)$ \\
Canada & $3.53(3.14)$ & $0.77(10.14)$ & $1.64(1.17)$ \\
Japan & $8.47(5.68)$ & $2.68(6.14)$ & $3.17(0.91)$ \\
France & $4.64(4.13)$ & $3.68(2.08)$ & $3.14(2.86)$ \\
Germany & $4.97(2.01)$ & $4.23(3.18)$ & $2.36(2.05)$ \\
Italy & $6.38(2.05)$ & $1.91(3.09)$ & $1.87(3.38)$ \\
U.K. & $4.02(5.67)$ & $3.32(23.59)$ & $2.91(9.27)$ \\
\hline Average & $4.88(3.81)$ & $2.23(9.57)$ & $2.44(3.37)$ \\
\hline \hline Sector & & & $1979-92$ \\
\hline Agriculture & $1960-73$ & $1973-79$ & $4.49(2.09)$ \\
Mining & $6.59(3.87)$ & $2.59(7.77)$ & $3.55(6.64)$ \\
Manufacturing & $5.67(17.07)$ & $1.83(97.82)$ & $2.82(0.98)$ \\
Utilities & $5.93(5.57)$ & $2.89(5.48)$ & $2.45(3.48)$ \\
Construction & $6.08(1.30)$ & $3.25(5.65)$ & $1.67(0.84)$ \\
Trade & $3.49(10.74)$ & $0.74(2.01)$ & $2.09(0.89)$ \\
Transport/ & $4.35(5.02)$ & $1.92(2.03)$ & $2.93(3.21)$ \\
Communication & $5.15(1.18)$ & $2.91(3.61)$ & $1.09(0.94)$ \\
FIRE & & $2.22(1.60)$ & $0.62(3.17)$ \\
Services & $2.40(5.94)$ & $1.42(2.32)$ & $2.41(2.37)$ \\
\hline Average & $3.52(7.03)$ & $2.20(14.25)$ & $2.27(1.84)$ \\
Ave. Excluding & $4.80(6.30)$ & $2.24(3.80)$ & \\
Mining & $4.69(4.95)$ & & \\
\hline
\end{tabular}




\section{TABLE 3}

Growth Rates of Output per Hour, the Contribution of Capital, and Multi-factor Productivity, Nonfarm Private Business Sector, 1960-92

\begin{tabular}{||lccccccccc||}
\hline & \multicolumn{3}{c}{ Output per Hour } & \multicolumn{3}{c}{ Contribution of Capital } & \multicolumn{3}{c||}{ Multi-factor Productivity } \\
\cline { 2 - 10 } & $\mathbf{1 9 6 0 - 7 3}$ & $\mathbf{1 9 7 3 - 7 9}$ & $\mathbf{1 9 7 9 - 9 2}$ & $\mathbf{1 9 6 0 - 7 3}$ & $\mathbf{1 9 7 3 - 7 9}$ & $\mathbf{1 9 7 9 - 9 2}$ & $\mathbf{1 9 6 0 - 7 3}$ & $\mathbf{1 9 7 3 - 7 9}$ & $\mathbf{1 9 7 9 - 9 2}$ \\
\hline United States & 1.92 & 0.46 & 1.20 & 0.57 & 0.60 & 0.82 & 1.35 & -0.14 & 0.38 \\
Canada & 3.02 & 1.27 & 1.41 & 0.72 & 0.91 & 1.45 & 2.30 & 0.36 & -0.04 \\
Japan & $\mathbf{8 . 2 3}$ & 3.08 & 3.22 & $-\ldots-$ & 1.79 & 1.59 & $-\ldots-$ & 1.29 & 1.63 \\
France & 4.90 & 3.94 & 2.55 & 1.26 & 1.55 & 0.98 & 3.64 & 2.39 & 1.57 \\
Germany & $\mathbf{5 . 3 3}$ & 4.38 & 2.36 & 1.90 & 1.69 & 0.92 & 3.43 & 2.69 & 1.44 \\
Italy & 6.71 & 1.99 & 1.90 & 1.15 & -0.64 & 0.19 & 5.56 & 2.63 & 1.71 \\
United & & & & & & & & & 1.16 \\
Kingdom & 3.53 & 2.20 & 1.27 & 1.21 & 1.04 & 0.05 & 2.32 & 1.16 & 1.22 \\
\hline
\end{tabular}




\section{TABLE 4}

Contribution of Capital and of MFP to Slowdown in Growth Rate of Output per Hour, 1979-92 as compared to $1960-73$, by Major Sector

\begin{tabular}{|c|c|c|c|c|c|c|c|c|c|}
\hline & \multicolumn{3}{|c|}{ Private Nonfarm Business } & \multicolumn{3}{|c|}{ Manufacturing } & \multicolumn{3}{|c|}{ Private NFNMNM $^{a}$} \\
\hline & Slowdown & $\begin{array}{c}\% \text { Share } \\
\text { Capital }\end{array}$ & $\begin{array}{c}\text { \% Share } \\
\text { MFP }\end{array}$ & Slowdown & $\begin{array}{c}\text { \% Share } \\
\text { Capital }\end{array}$ & $\begin{array}{c}\text { \% Share } \\
\text { MFP }\end{array}$ & Slowdown & $\begin{array}{c}\text { \% Share } \\
\text { Capital }\end{array}$ & $\begin{array}{c}\text { \% Share } \\
\text { MFP }\end{array}$ \\
\hline $\begin{array}{l}\text { United } \\
\text { States }\end{array}$ & -0.72 & -35 & 135 & -0.78 & -40 & 140 & -0.71 & -24 & 124 \\
\hline Canada & -1.61 & -45 & 145 & -2.03 & -49 & 149 & -1.03 & -61 & 161 \\
\hline France & -2.35 & 12 & 88 & -4.05 & 4 & 96 & -1.52 & 26 & 74 \\
\hline Germany & -2.97 & 33 & 67 & -3.83 & 24 & 76 & -2.32 & 54 & 46 \\
\hline Italy & -4.81 & 20 & 80 & -3.02 & -11 & 110 & -5.49 & 27 & 73 \\
\hline $\begin{array}{l}\text { United } \\
\text { Kingdom }\end{array}$ & -2.26 & 51 & 49 & 0.66 & 88 & 12 & -2.07 & 51 & 49 \\
\hline
\end{tabular}




\section{TABLE 5}

\section{Regression Equations Explaining Growth Rates by Country and Sector, Three Intervals, 1960-92}

\begin{tabular}{|c|c|c|c|c|c|}
\hline & \multicolumn{3}{|c|}{ Output per Hour } & \multirow{2}{*}{$\begin{array}{c}\begin{array}{c}\text { Capital per } \\
\text { Potential Hour }\end{array} \\
(4)\end{array}$} & \multirow{2}{*}{$\begin{array}{c}\text { Multifactor } \\
\text { Productivity } \\
(5)\end{array}$} \\
\hline & (1) & (2) & (3) & & \\
\hline Constant & $2.55^{* *}$ & $4.77^{* *}$ & $5.12^{* *}$ & $4.93^{* *}$ & $4.33^{* *}$ \\
\hline $\begin{array}{l}\text { Productivity Level } \\
\text { Relative to U.S. }\end{array}$ & $\cdots$ & $-2.45^{* *}$ & $-2.48^{* *}$ & $-2.63^{* *}$ & $-2.36^{*}$ \\
\hline $\begin{array}{l}\text { Change in } \\
\text { Unemployment }\end{array}$ & -0.46 & -0.43 & --- & $-0.56^{*}$ & $-\cdots$ \\
\hline Canada & $1.37^{*}$ & 0.35 & -0.06 & 0.27 & -0.48 \\
\hline France & $3.81^{* *}$ & $2.34^{* *}$ & 1.35 & $2.45^{* *}$ & 0.68 \\
\hline Germany & $3.35^{* *}$ & $2.34^{* *}$ & $1.68^{* *}$ & $2.29^{* *}$ & 0.91 \\
\hline Italy & $2.48 * *$ & $2.79 * *$ & $2.28^{* *}$ & $1.97^{* *}$ & $2.10^{* *}$ \\
\hline U.K. & $3.55^{* *}$ & $2.36^{* *}$ & $1.43^{*}$ & $1.78^{*}$ & 0.75 \\
\hline Agriculture & $1.53^{*}$ & 0.87 & 0.86 & 0.96 & $-1.74^{* *}$ \\
\hline Mining & -0.64 & -0.68 & -0.68 & $2.28^{* *}$ & $-1.63^{* *}$ \\
\hline Utilities & 0.42 & 0.36 & 0.36 & -0.93 & -0.43 \\
\hline Construction & $-1.87^{* *}$ & $-2.13^{* *}$ & $-2.13^{* *}$ & -0.38 & $-2.07^{* *}$ \\
\hline $\begin{array}{l}\text { Transport' } \\
\text { Communication }\end{array}$ & 0.11 & 0.17 & 0.16 & -1.47 & 0.56 \\
\hline Trade & -0.11 & -0.90 & -0.89 & -0.30 & -1.02 \\
\hline FIRE & $-1.99 * *$ & $-2.13^{* *}$ & $-2.14^{* *}$ & $-2.77^{* *}$ & $-2.16^{* *}$ \\
\hline Services & $-1.76^{* *}$ & -1.30 & -1.29 & -0.32 & $-1.67^{* *}$ \\
\hline $1973-79$ & $-1.41^{* *}$ & $-1.12^{*}$ & $-1.65^{* *}$ & 0.10 & $-1.33^{* *}$ \\
\hline $1979-92$ & -0.74 & -0.23 & $-1.28^{* *}$ & 0.13 & $-0.82^{*}$ \\
\hline$\overline{\mathrm{R}}^{2}$ & 0.34 & 0.39 & 0.39 & 0.43 & 0.37 \\
\hline S.E.E. & 2.30 & 2.20 & 2.21 & 2.19 & 1.90 \\
\hline
\end{tabular}

Note: * Indicates that coefficient is significant at 5 percent level; ** at 1 percent level. 


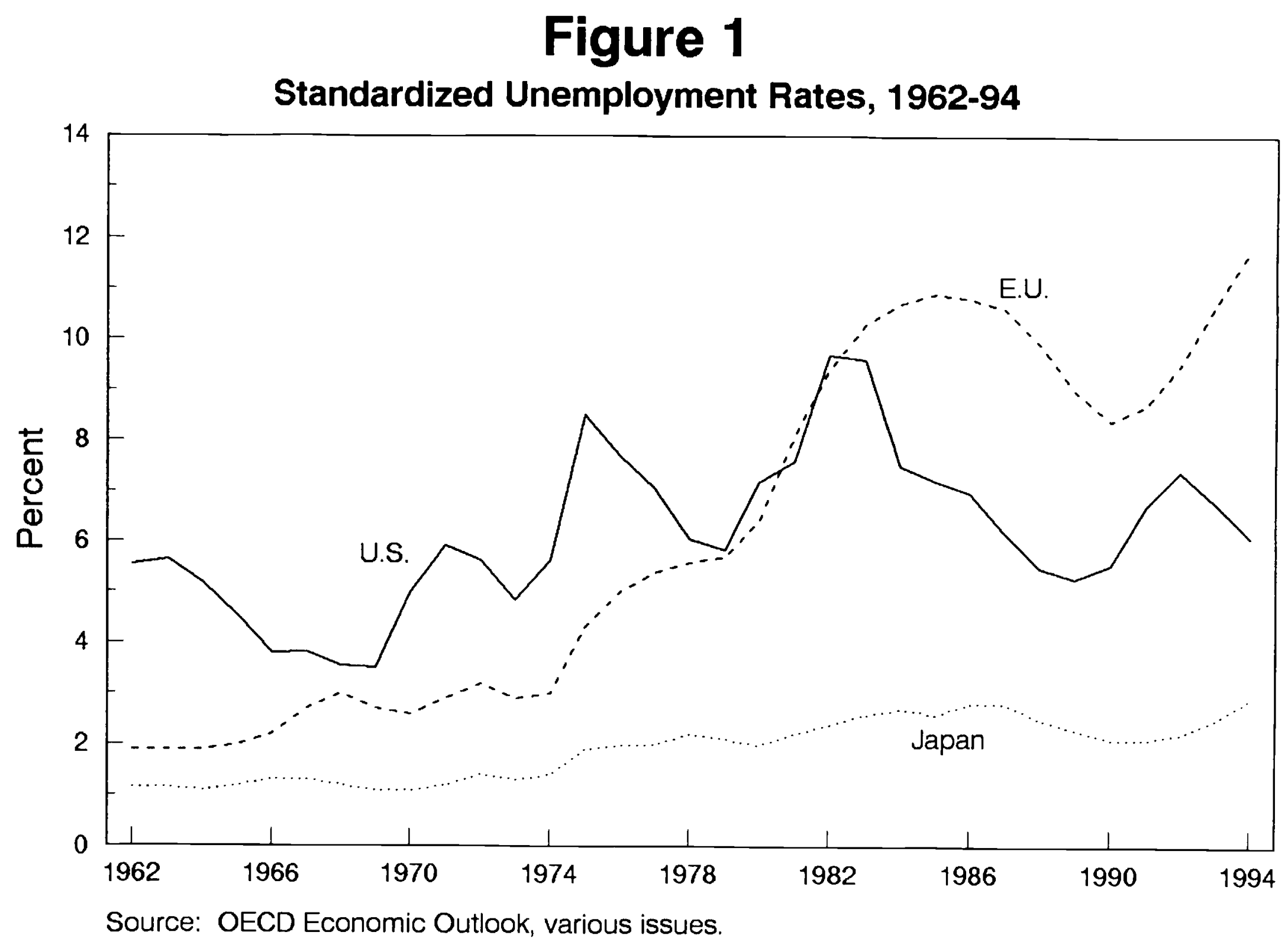




\section{Figure 2}

Percentage of 15-64 year-olds Working in the U.S and Western Europe, Adjusted for Hours

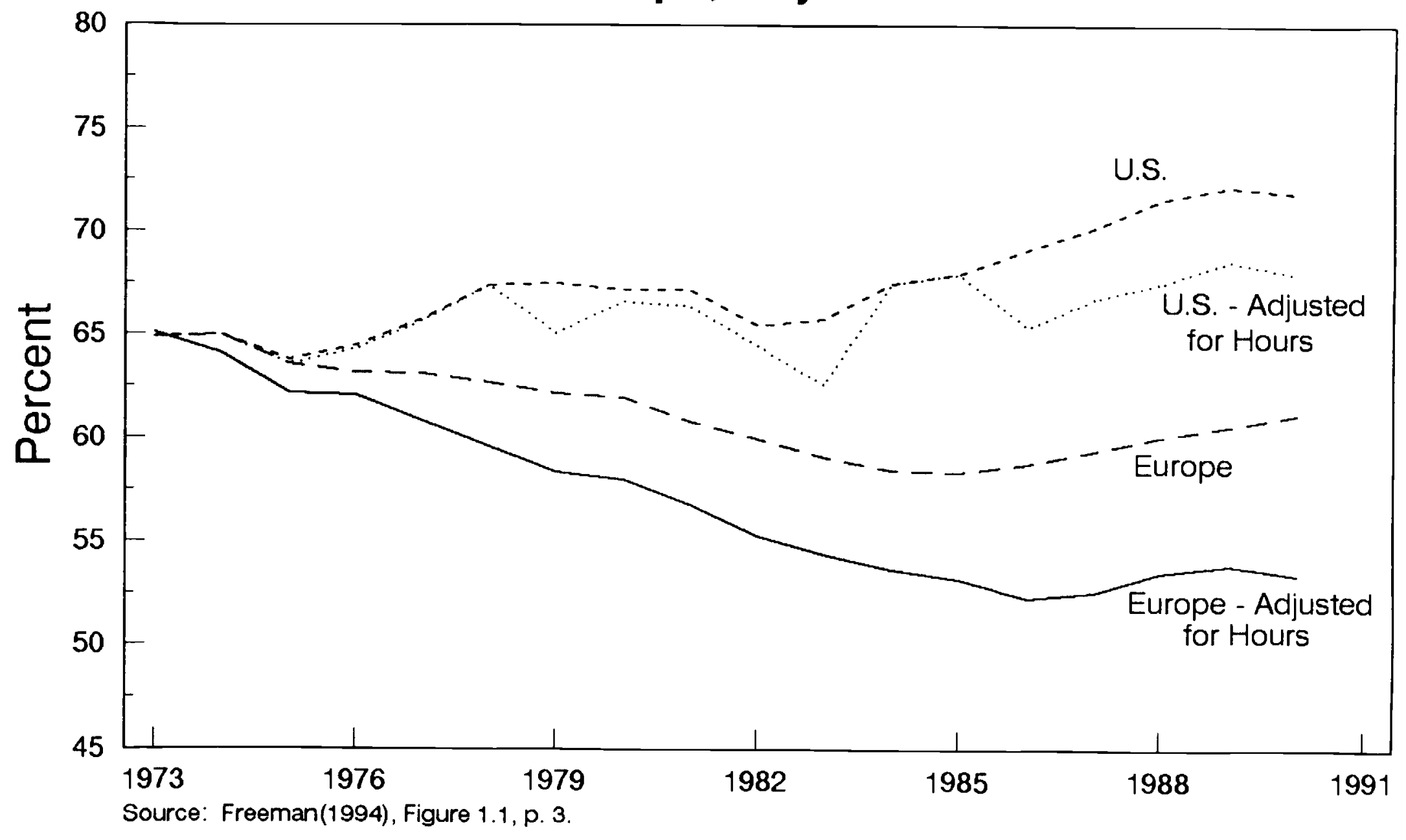




\section{Figure 3}

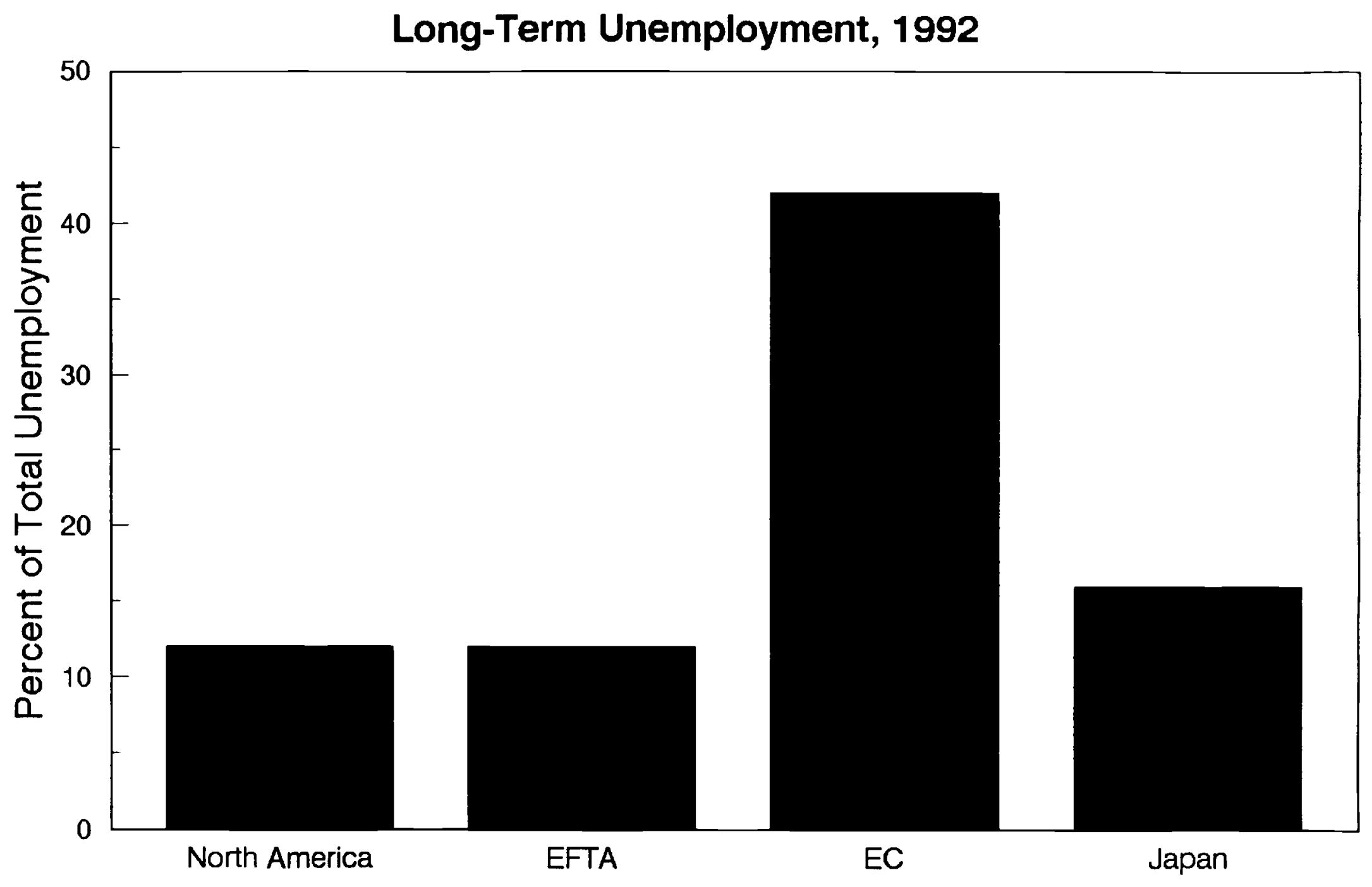

Source: OECD Jobs Study (1994), Chart 4, p. 12. 


\section{Figure 4}

\section{Multi-Factor Productivity Growth by Region and Interval, 1960-93}

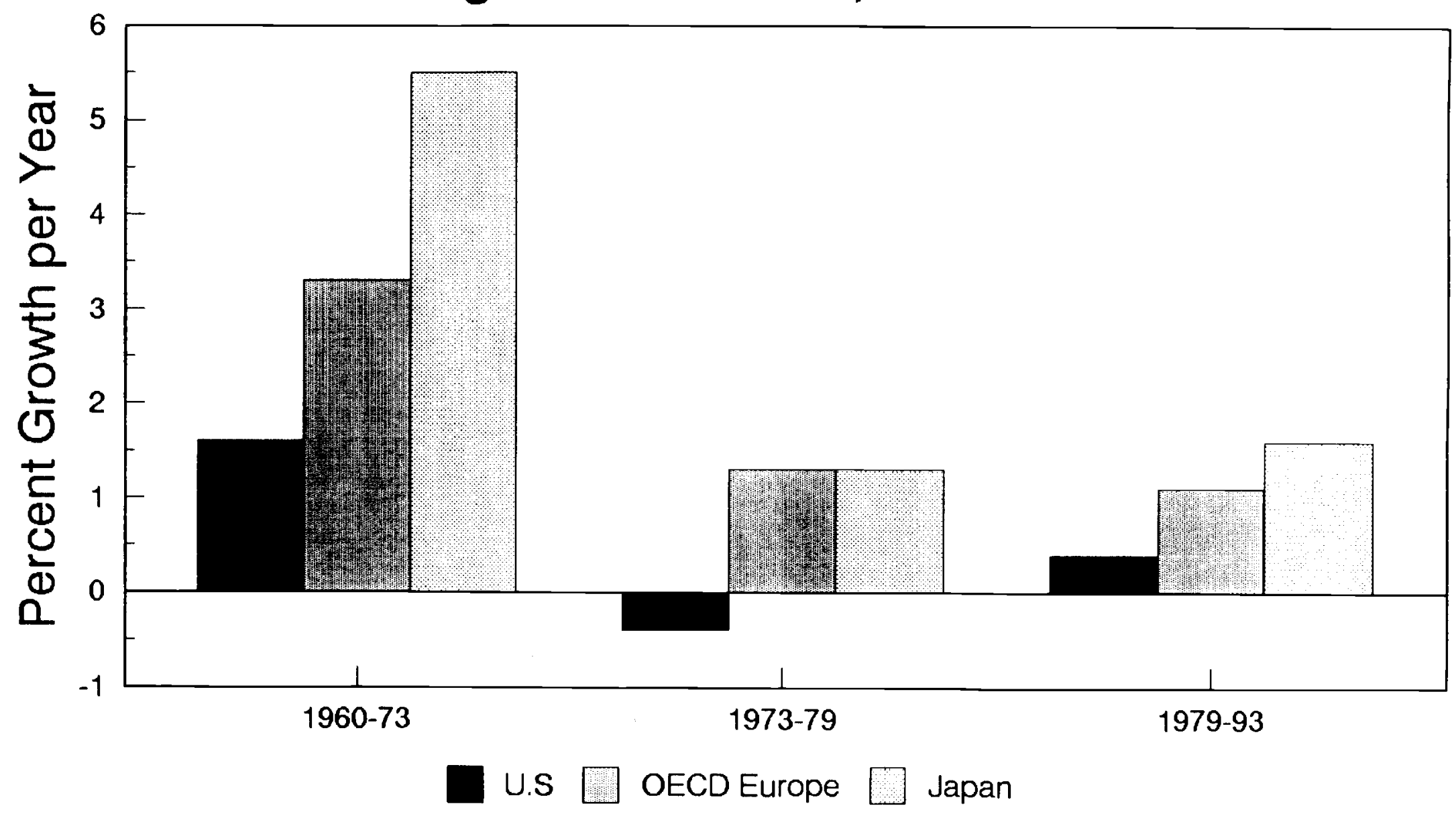

Source: OECD Economic Outlook, December 1994, Annex Table 58. 
Figure 5

Wage Shares by Region, 1970-93

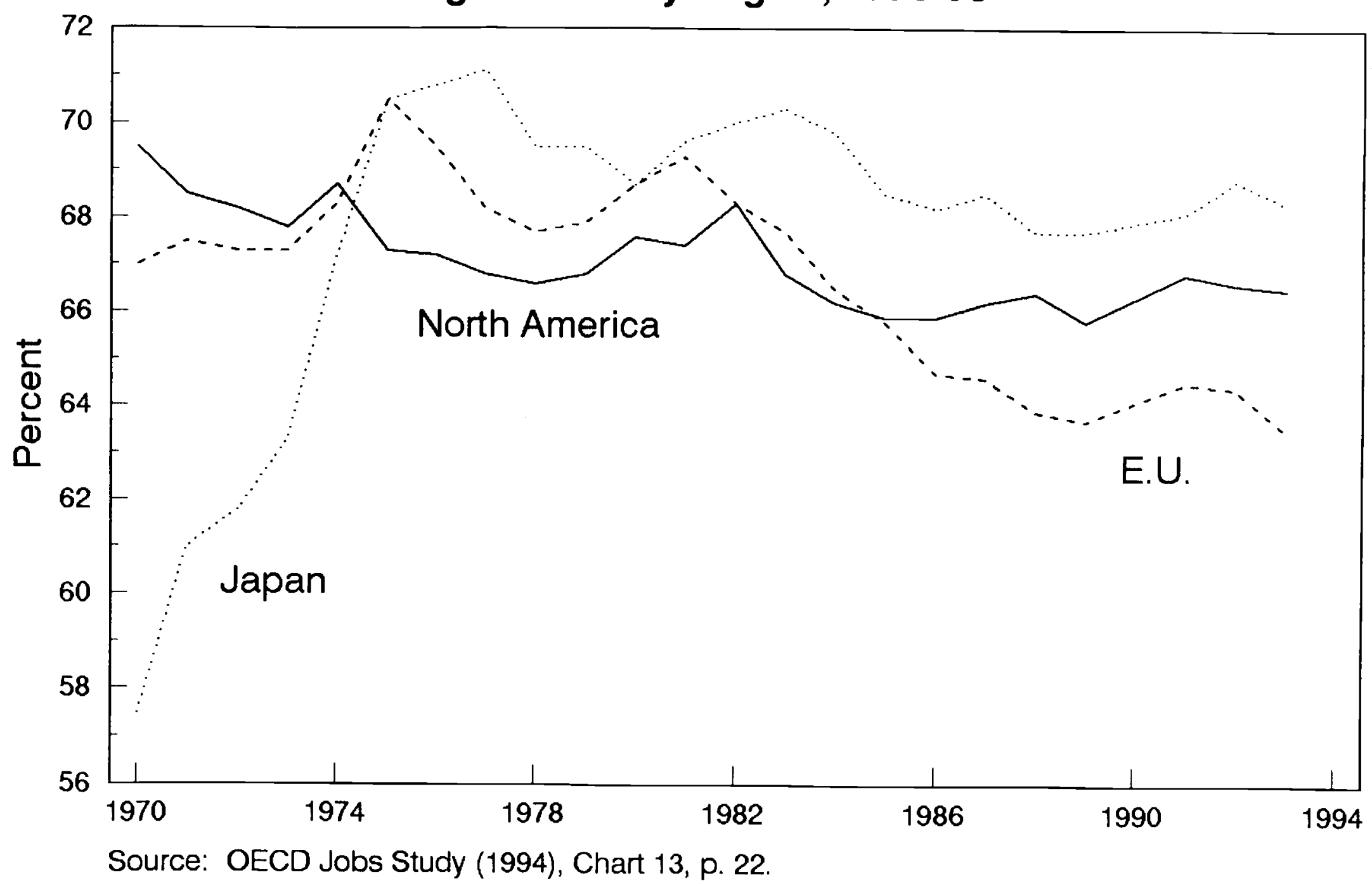


Figure 6

Growth in Real Wages of

Low-Paid Workers, 1980-92

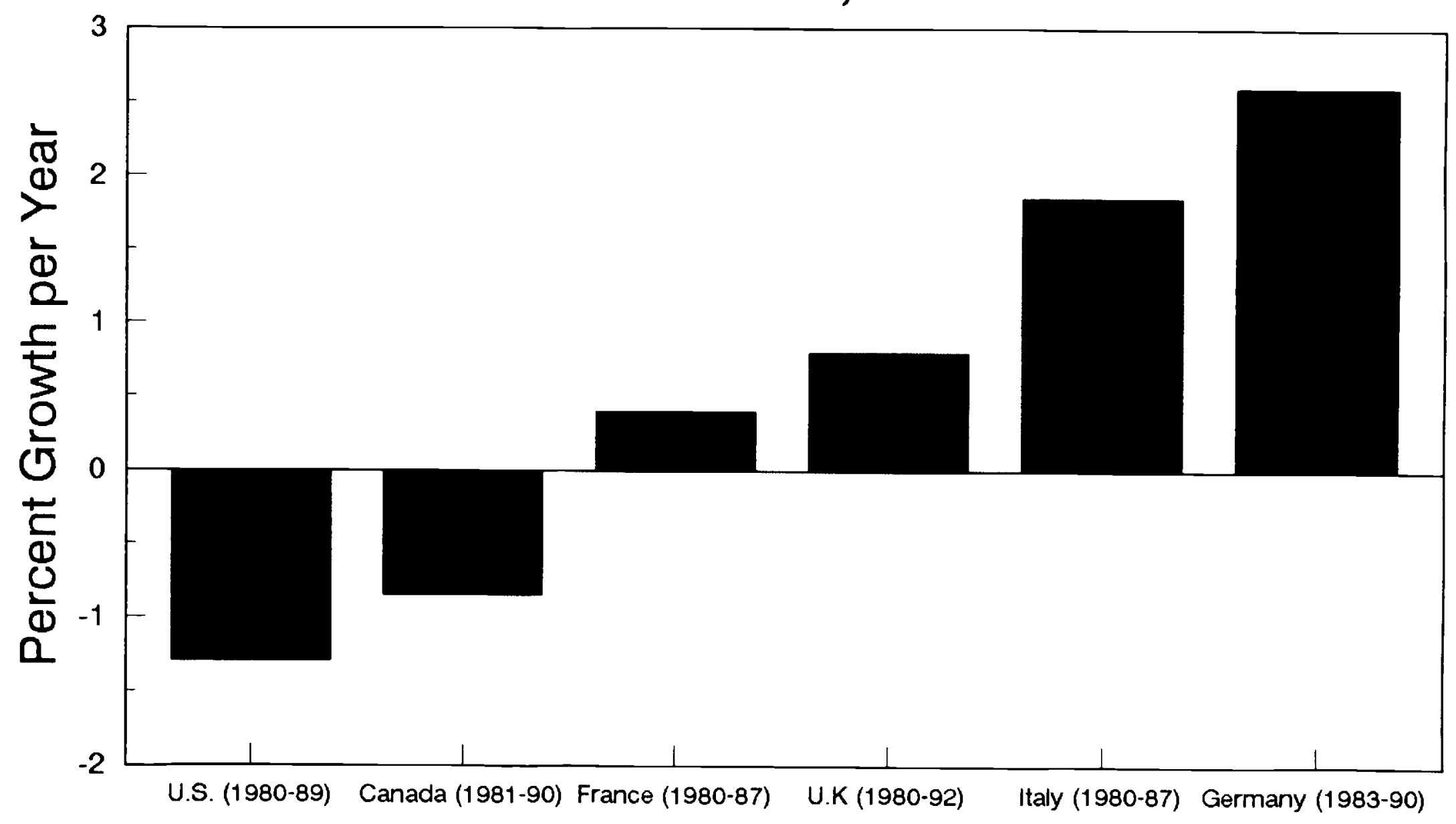

Source: OECD Jobs Study (1994), Chart 14, p. 22. 


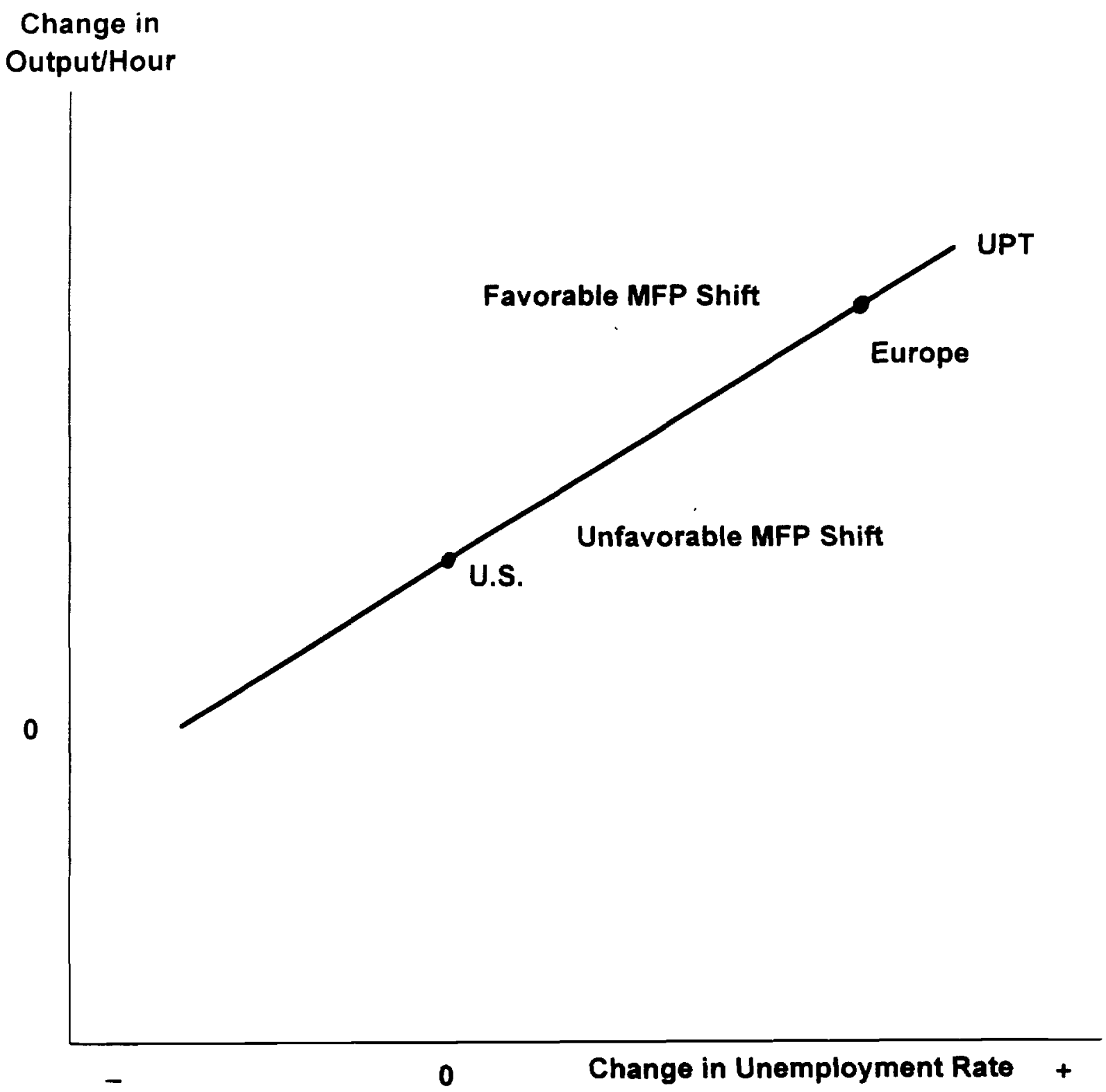

\section{FIGURE 7}

The Unemployment-Productivity

Tradeoff (UPT) Schedule 


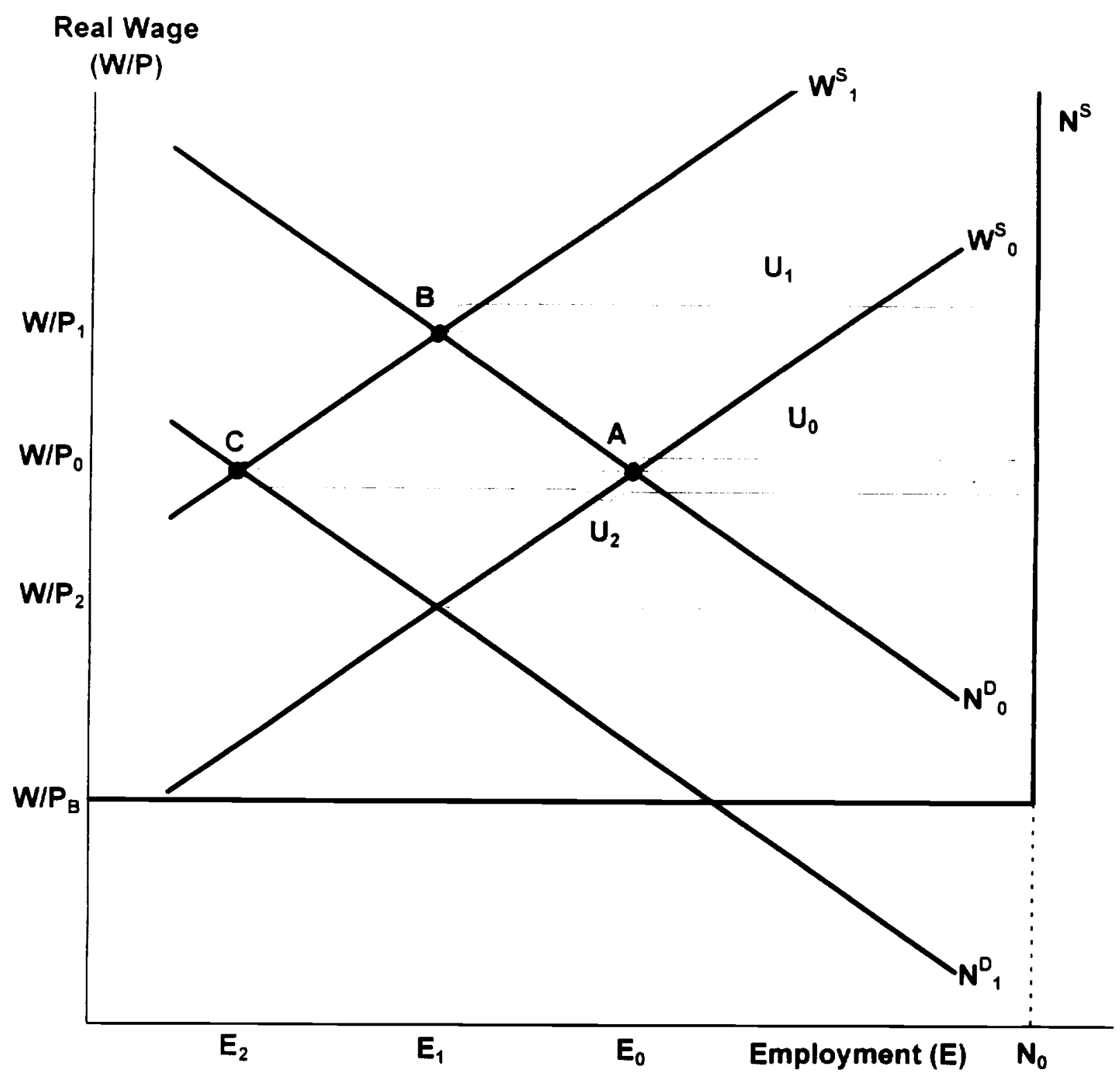

FIGURE 8

Unemployment and Productivity in the Standard Labor-Market Model 


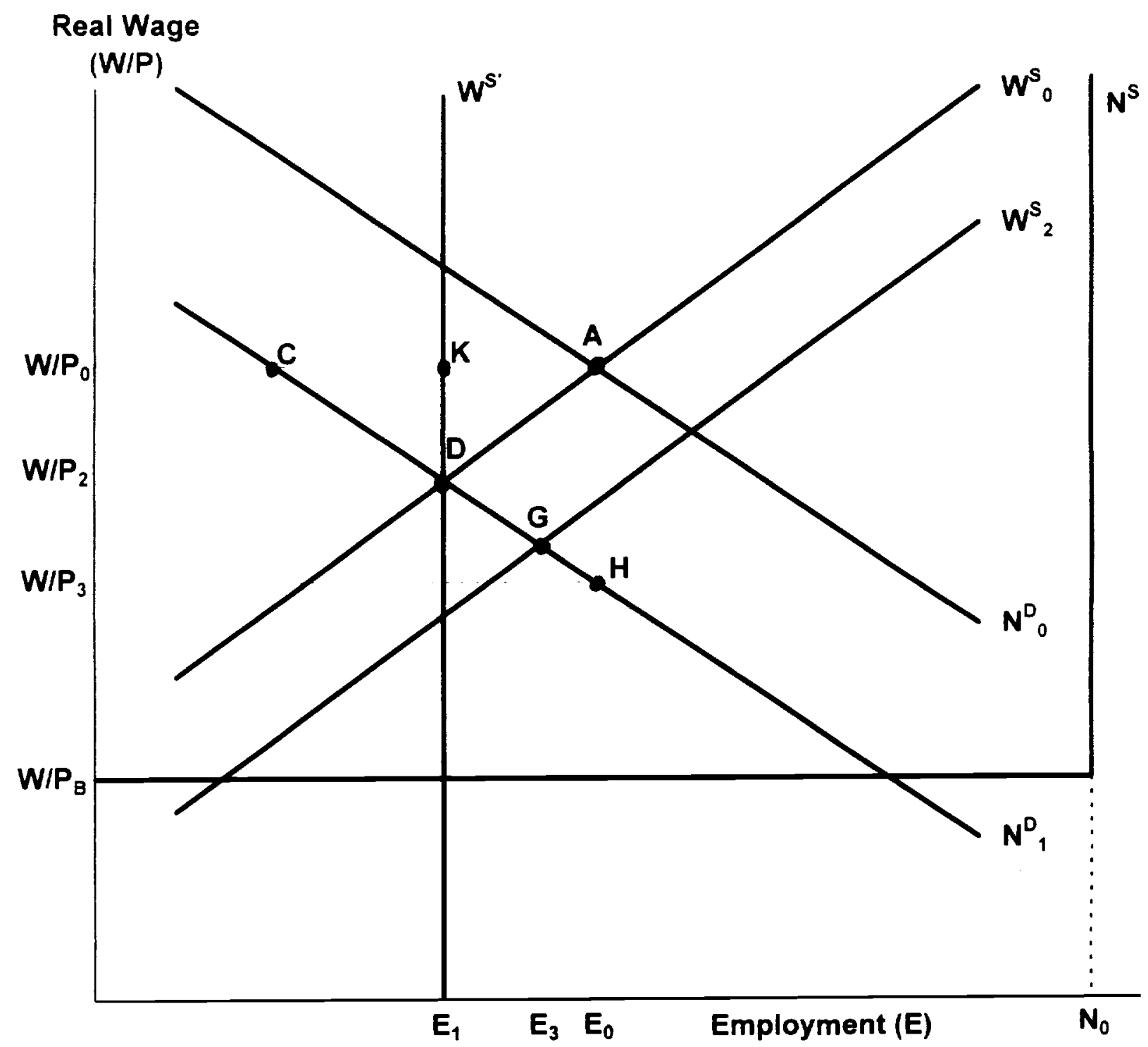

FIGURE 9

Effects of an Oil Shock on

Employment and the Real Wage 
Figure 10

Minimum Wage Relative to Average Hourly

Compensation, 1962-92

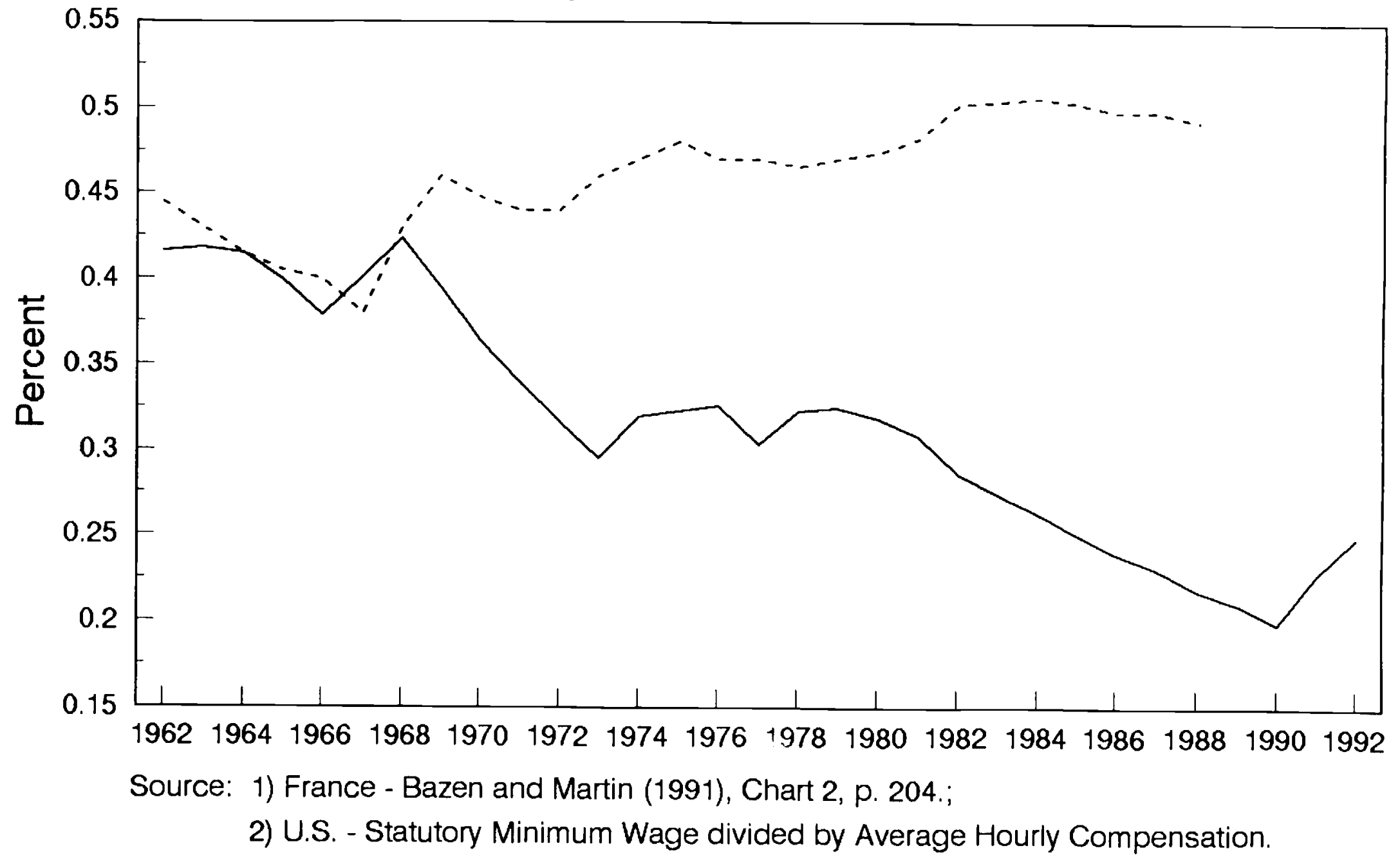




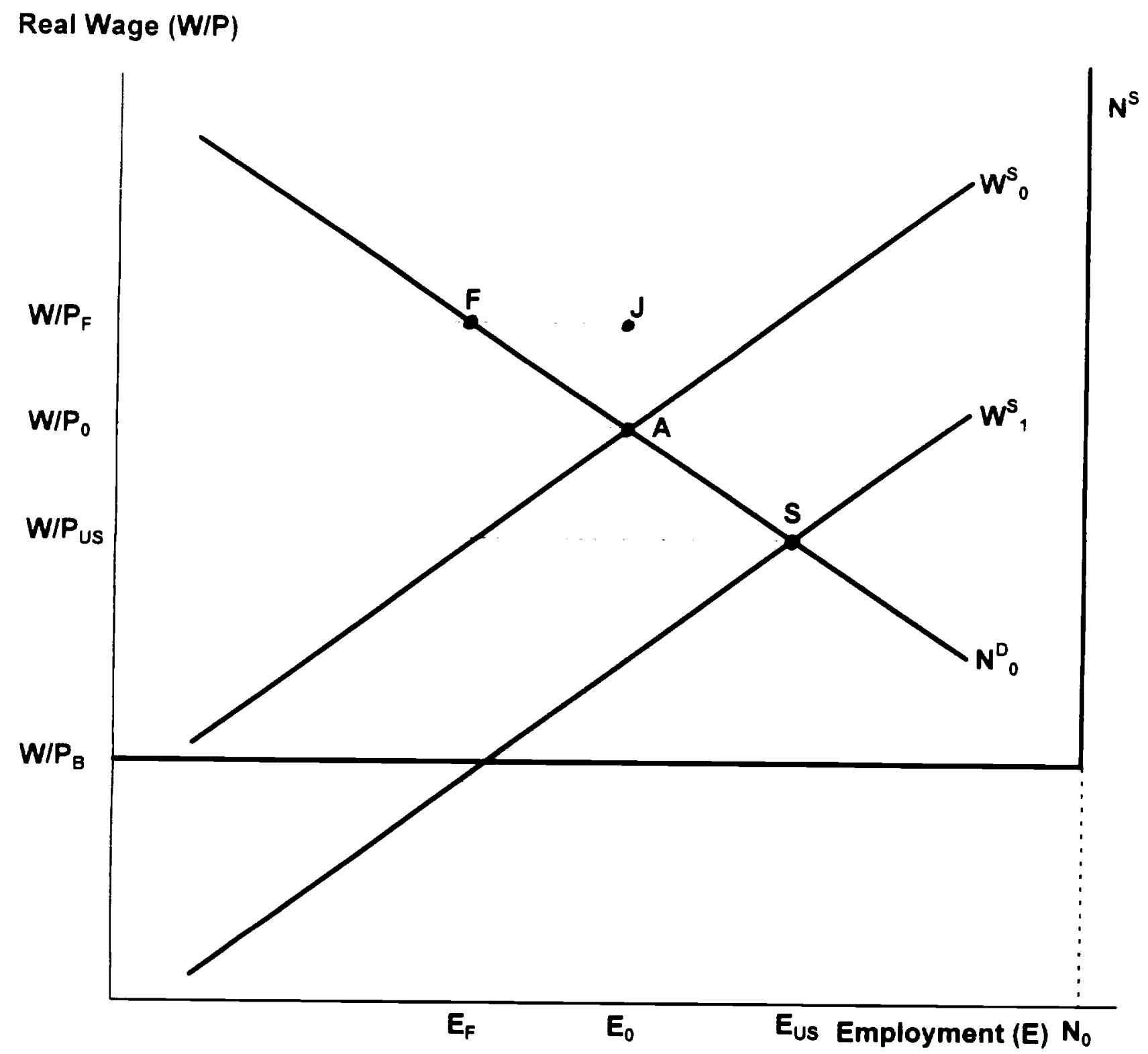

FIGURE 11

Effect of an Increase in the Real Minimum Wage in France and a Decrease in the U.S. 
Change in
Output/Hour

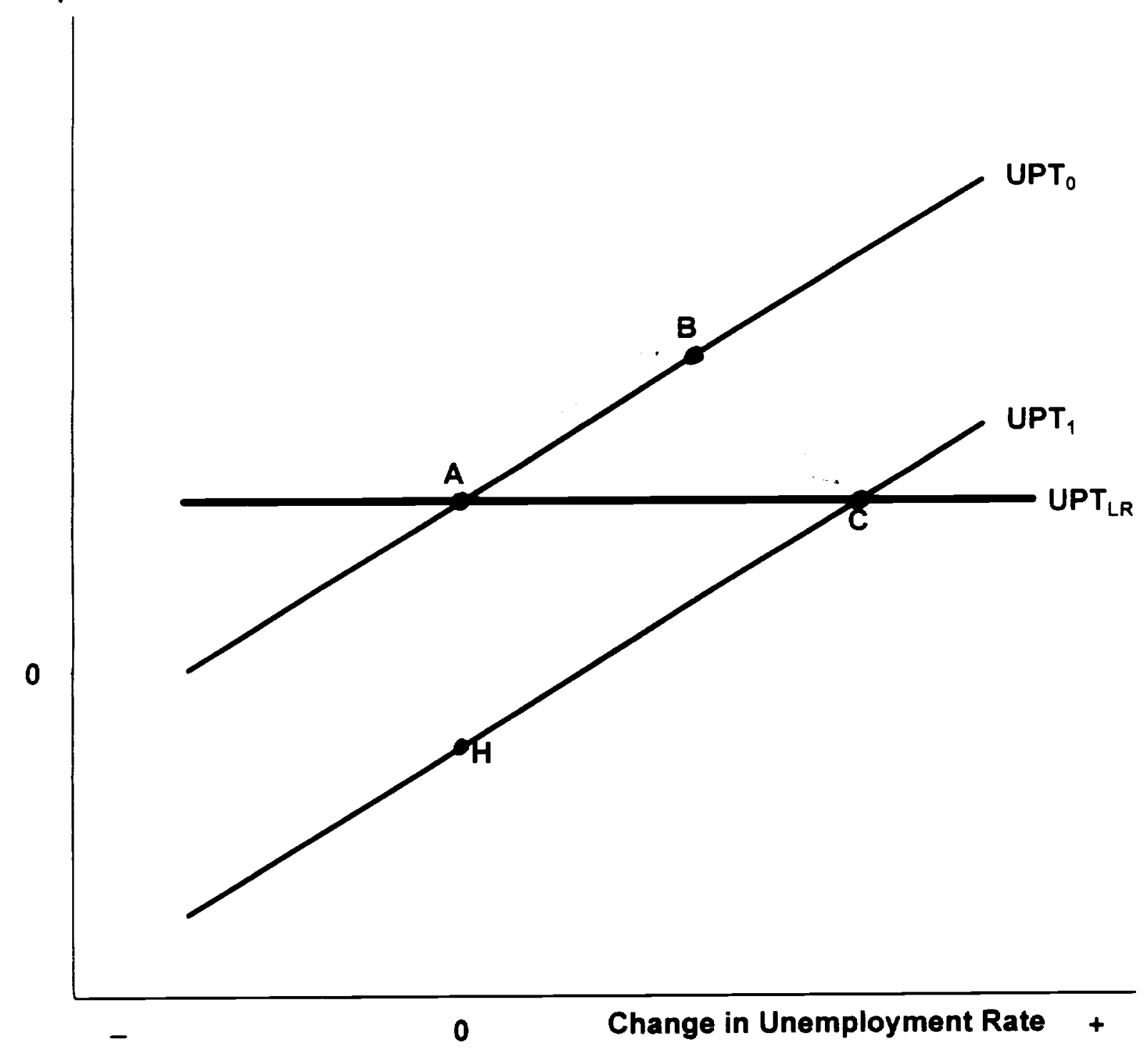

FIGURE 12

Movements Along and Shifts in the UPT Schedule 